\title{
Early Spears as Thrusting Weapons: Isolating force and impact velocities in human performance trials
}

\author{
Annemieke Milks a,*, Stephen Champion ${ }^{\mathrm{b}}$, Elizabeth Cowper ${ }^{\mathrm{bc}}$, Matt Pope ${ }^{\mathrm{a}}$, Debra \\ Carr ${ }^{b}$

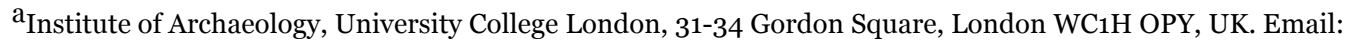 \\ Annemieke Milks: a.milks@ucl.ac.uk Matt Pope: m.pope@ucl.ac.uk

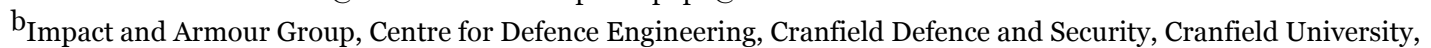 \\ Defence Academy of the United Kingdom, Shrivenham, Oxon SN6 8LA, UK. Email: Stephen Champion: \\ s.m.champion@cranfield.ac.uk Debra Carr: d.j.carr@cranfield.ac.uk \\ ${ }^{c}$ Centre for Advanced Materials and Performance Textiles, RMIT University, 25 Dawson Street, Brunswick, VIC 3056, \\ Australia. Email: Libby Cowper : libby.cowper@rmit.edu.au
}

\begin{abstract}
Human hunting has been a cornerstone of research in human evolutionary studies, and decades worth of research programmes into early weapon systems have improved our understanding of the subsistence behaviours of our genus. Thrusting spears are potentially one of the earliest hunting weapons to be manufactured and used by humans. However, a dearth of data on the mechanics of thrusting spear use has hampered experimental research. This paper presents a human performance trial using military personnel trained in bayonet use. Participants thrusted replicas of Middle Pleistocene wooden spears into PermaGel ${ }^{\mathrm{TM}}$. For each spear thrust, impact velocity was recorded with high-speed video equipment, and force profiles were recorded using a force transducer. The results demonstrate that training improves performance when compared with previous experimental results using untrained participants, and that the mechanics and biomechanics of spear thrusting are complex. The trial confirms that previous spear thrusting experiments firing spears as projectiles are failing to replicate the entire spear thrusting event, and that crossbows are too powerful to replicate the low velocities involved in spear thrusting. In order to better understand evidence of spear thrusting in the archaeological record, experimental protocols accurately replicating and recording the mechanics of spear thrusting in the past are proposed.
\end{abstract}

Keywords: weapon delivery systems, Middle Pleistocene, projectiles, experiment, untipped wooden spears

\footnotetext{
${ }^{*}$ Corresponding Author. Tel: +44 (0) 2076797495 Email: a.milks@ucl.ac.uk
} 


\section{Introduction: replicating and recognising thrusting spears in prehistory}

The use of weaponry throughout human evolution has far-reaching implications for understanding human subsistence behaviours, interpersonal violence and self-defence against both animals and other humans (Churchill et al., 2009; Shea, 2006). These implications are most significant for understanding changes in cognitive or physiological capacities of earlier species of Homo as opposed to anatomically modern humans (e.g. Churchill, 1993; Churchill and Rhodes, 2009; McBrearty and Brooks, 2000; Rhodes and Churchill, 2009; Roach et al., 2013; Roach and Richmond, 2015; but see Lombard and Parsons, 2010), with the role of weapons contributing to recent discussions on hunting and scavenging strategies (e.g. Hardy et al., 2013; Villa and Soriano, 2010), human dispersal events (e.g. Shea \& Sisk 2010; Sisk \& Shea 2011) and tool use amongst extant primates (Huffman \& Kalunde 1993; Pruetz \& Bertolani 2007). While a significant trend in research has involved better understanding 'complex' projectile technologies, i.e. those mechanically aided such as spearthrowers and bow-and-arrows, much of the focus has recently shifted to an interest in hand-delivered thrusting and throwing spears, including those with hafted lithic points as well as untipped wooden spears (Hutchings, 2011; Iovita et al., 2016; Rieder, 2001; Schmitt et al., 2003; Shea et al., 2002; 2001; Wilkins et al., 2014a).

A better understanding of the timing of the development of weapon systems is not just a matter of interest in and of itself, as the development of weaponry has long been seen as key to understanding the abilities of our hominin ancestors to hunt ever more successfully with progressively complex technologies (e.g. Dart, 1949; Darwin, 1871; McBrearty and Brooks, 200o; Shea and Sisk, 2010; Washburn et al., 1968) . A simplified unilinear model of the evolution of weaponry suggests that thrusting spears were an early weapon, although the timing of their appearance remains poorly understood (Rieder, 2003; Shea, 2006; Shea and Sisk, 2010; Wilkins et al. 2014a; 2012; Iovita et al. 2016). The hand-delivered throwing spear, presumably coincident with or subsequent to the human capacity for throwing, is generally thought to 
have emerged after the first use of thrusting spears, though the timing of this is debated as well (Iovita et al., 2016; Rhodes and Churchill, 2009; Roach and Richmond, 2015).

The ability to distinguish between different weapon systems, for example by identifying delivery-dependent ballistic properties and usewear on lithic points would, according to the linear model, help to understand the timing of the appearance of weapon systems (Shea, 2006; Hutchings, 2011; Iovita et al., 2014). Leaving aside issues thrown up by the persistence of both untipped and composite hand-delivered spears amongst modern hunter-gatherer groups either alongside or in the absence of 'complex' projectile technologies (e.g. Driver, 1939; Goodale, 1994; Hiatt, 1968; Hitchcock and Bleed, 1997; Moseley, 1877; Spencer, 1914; Swanton, 1946), the search for these data is hampered by a poor understanding of the mechanics and biomechanics of hand-delivered weapons, with experimental work relying upon estimates of impact velocities and forces involved (e.g. Iovita et al., 2016; Shea et al., 2002; 2001; Wilkins et al. 2014a).

The earliest complete weapons in the archaeological record are a collection of 10 untipped wooden spears from Schöningen, Germany dating to MIS 9 (Richter and Kerbetschek, 2015; Thieme, 1997; Schoch et al., 2015; Urban et al., 2011). A broken tip of a wooden implement, with a tip morphology similar to the collection of spears from Schöningen, comes from Clacton-on-Sea and probably dates to MIS 11 (Bridgland et al., 1999; Oakley et al., 1977). Interpretation of the function of these Middle Pleistocene wooden spears has varied and has included thrusting spears, hand-thrown spears and snow probes for locating carcasses (e.g. Gamble, 1987; Oakley et al., 1977; Schmitt et al., 2003; Thieme, 1997). Particularly in light of recent Homotherium latidens finds from the 'spear horizon' at Schöningen, and possible evidence of interpersonal violence at Sima de los Huesos dating to MIS 11, other possibilities include weapons for self-defence and violence amongst conspecifics (Sala et al., 2015; Serangeli et al., 2014). However, given the abundance of butchered zooarchaeological remains, in particular at least 46 Equus mosbachensis thus far described from Schöningen 13 II-4 (van 
Kolfschoten 2014), an interpretation of these finds as hunting weapons remains a reasonable functional assignment.

With the 'spear horizon' at Schöningen probably corresponding to MIS 9, candidates for the species that made these weapons include $H$. heidelbergensis or possibly early $H$. neanderthalensis (Conard et al., 2015; Street et al., 2006; Stringer, 2012). Male H. heidelbergensis had an estimated mean body mass of $79.3 \mathrm{~kg}$, compared with estimates of between $66.5 \mathrm{~kg}-$ $69.2 \mathrm{~kg}$ for Palaeolithic male H. sapiens (Froehle et al., 2013) and an estimate of $49 \mathrm{~kg}$ for $H$. erectus (Hatala et al., 2016). Stature estimates for $H$. heidelbergensis are around $175 \mathrm{~cm}$ (Stringer et al., 1998). The stature and body mass estimates for $H$. heidelbergenis imply a powerfully built, robust species of human.

In a landmark paper on prehistoric weapon technology, Susan Hughes (1998) identified a lack of reported data on thrusting spears, not only restricted to design of lithic tips of composite thrusting spears, but also on the forces and velocities that might occur during spear thrusting. Shea et al. (2001, p.809) reiterated this absence of data, thus relying on data from one-handed stabbing experiments to design their controlled experiment investigating Levallois point-tipped thrusting spears. The one-handed stabbing experiments to which Shea et al. (2001) referred were conducted to understand the effects of knife stabbing (Table 1), in order to design appropriate clothing for law enforcement officers (Horsfall et al., 1999; Miller and Jones, 1996). However, the mechanics and biomechanics of one-handed stabbing are different from twohanded spear thrusting, and the weapon considered in this previous work (a knife) is different from a thrusting spear in mass, morphology and material, rendering use of these data not appropriate. Controlled experiments aiming to replicate two-handed spear thrusting continue to rely on estimates of velocity and force, with a wide range of velocities being tested, spanning from $1.0 \mathrm{~m} / \mathrm{s}$ to $10.3 \mathrm{~m} / \mathrm{s}$ (Table 2) (e.g. Iovita et al., 2016; Shea et al., 2001; Wilkins et al., 2014a; 2014b) and with force rarely being replicated (but see Iovita et al., 2016). The use of such a wide range of impact velocities calls into question results relating to the effectiveness of the weapons tested and damage caused 
to lithic points, and makes comparison of results between experiments problematic. In comparison, Schmitt et al. (2003) provided experimental data on thrusting spears, using aluminium poles on a 'padded' target, but the experiment was designed to understand the forces acting on the human body during two-handed spear thrusting in order to aid the identification of spear use on human fossil material. This difference in objective led to an underreporting of data on impact velocities, an absence of data on forces imparted on the spear itself, and the use of untrained participants. A more useful study aimed at understanding differences in grips in one-handed spear thrusting in antiquity captured forces and velocities with a force transducer and accelerometer, albeit with one participant conducting a small number of thrusts $(\mathrm{n}=11)$ with a 1350 gram metal-tipped spear at a padded target (Connolly et al., 2001).

Table 1. Impact velocities from previous studies.

\begin{tabular}{|c|c|c|c|c|c|}
\hline Type experiment & $\begin{array}{l}\text { Velocity } \\
\text { (range) }\end{array}$ & $\begin{array}{l}\text { Velocity } \\
\text { (mean) }\end{array}$ & $\begin{array}{l}\text { Velocity } \\
\text { Estimated or } \\
\text { Filmed }\end{array}$ & $\begin{array}{l}\text { Firing } \\
\text { mechanism }\end{array}$ & Source \\
\hline $\begin{array}{l}\text { Human Performance } \\
\text { One-handed stabbing: } \\
\text { overarm and } \\
\text { underarm }\end{array}$ & $6-10 \mathrm{~m} / \mathrm{s}$ & $\begin{array}{l}5.8 \mathrm{~m} / \mathrm{s} \\
\text { (underhand) } \\
8.9 \mathrm{~m} / \mathrm{s} \\
\text { (overhand) } \\
(n=203)\end{array}$ & $\begin{array}{l}\text { Calculated via } \\
\text { acceleration data, } \\
\text { verified with high } \\
\text { speed video for } \\
\text { some trials }\end{array}$ & $\begin{array}{l}\text { Humans ( } n=\text { not } \\
\text { reported), mixed } \\
\text { male/female }\end{array}$ & $\begin{array}{l}\text { Horsfall et } \\
\text { al., } 1999\end{array}$ \\
\hline $\begin{array}{l}\text { Human Performance } \\
\text { One-handed stabbing: } \\
\text { overhand, short } \\
\text { forward thrust, side } \\
\text { sweep }\end{array}$ & $\begin{array}{l}2.6-9.2 \\
\mathrm{~m} / \mathrm{s}\end{array}$ & $\begin{array}{l}5.8 \mathrm{~m} / \mathrm{s} \\
(n=600)\end{array}$ & $\begin{array}{l}\text { Six-camera VICON } \\
\text { motion analysis } \\
\text { system }\end{array}$ & $\begin{array}{l}\text { Humans }(n=20), \\
\text { mixed male/female, } \\
\text { mixed students and } \\
\text { trained police }\end{array}$ & $\begin{array}{l}\text { Chadwick } \\
\text { et al., } 1999\end{array}$ \\
\hline $\begin{array}{l}\text { Human Performance } \\
\text { One-handed stabbing: } \\
\text { short underhand, } \\
\text { short overhand, long } \\
\text { underhand, long } \\
\text { overhand }\end{array}$ & $\begin{array}{l}5.8-12.0 \\
\mathrm{~m} / \mathrm{s}\end{array}$ & $\begin{array}{l}6.6 \mathrm{~m} / \mathrm{s} \text { short } \\
\text { underhand; } \\
\text { 7.o long } \\
\text { underhand; } \\
\text { 9.1 short } \\
\text { overhand; } 12 \\
\mathrm{~m} / \mathrm{s} \text { long } \\
\text { overhand } \\
\text { ( } n=10 \text { stabs } \\
\text { each type) }\end{array}$ & $\begin{array}{l}\text { Filmed, standard } \\
\text { video recorder } \\
\text { (Panasonic M10 } \\
\text { video recorder) }\end{array}$ & $\begin{array}{l}\text { Humans }(n=10) \text {, } \\
\text { mixed male/female }\end{array}$ & $\begin{array}{l}\text { Miller and } \\
\text { Jones, } \\
1996\end{array}$ \\
\hline $\begin{array}{l}\text { Human Performance } \\
\text { One-handed slashing; } \\
\text { various types and } \\
\text { directions }\end{array}$ & $\begin{array}{l}\text { Minimum } \\
\text { not } \\
\text { reported; } \\
\text { maximum } \\
14.88 \text { (all } \\
\text { directions) }\end{array}$ & $5.94 \mathrm{~m} / \mathrm{s}$ & $\begin{array}{l}\text { Estimated via } \\
\text { calculating length of } \\
\text { slash on paper and } \\
\text { time (Seconds) to } \\
\text { make slash) }\end{array}$ & $\begin{array}{l}\text { Humans }(n=87) \\
\text { mixed male/female }\end{array}$ & $\begin{array}{l}\text { Bleetman } \\
\text { et al., } 2003\end{array}$ \\
\hline $\begin{array}{l}\text { Human Performance } \\
\text { Two-handed spear } \\
\text { thrusting }\end{array}$ & $1.7-4.5 \mathrm{~m} / \mathrm{s}$ & Not reported & $\begin{array}{l}\text { Filmed, standard } \\
\text { video recorder, } 60 \\
\text { frames per second }\end{array}$ & $\begin{array}{l}\text { Humans }(n=7) \text {, } \\
\text { mixed male/female } \\
\text { (untrained) }\end{array}$ & $\begin{array}{l}\text { Schmitt et } \\
\text { al., } 2003\end{array}$ \\
\hline $\begin{array}{l}\text { Human Performance } \\
\text { One-handed spear } \\
\text { thrusting }\end{array}$ & $3.3-6.7 \mathrm{~m} / \mathrm{s}$ & $\begin{array}{l}4.7 \mathrm{~m} / \mathrm{s}(\mathrm{n}=11 \\
\text { stabs all grips } \\
\text { combined) }\end{array}$ & $\begin{array}{l}\text { Calculated via } \\
\text { acceleration data }\end{array}$ & $\begin{array}{l}\text { Human }(\mathrm{n}=1) \\
\text { male (trained) }\end{array}$ & $\begin{array}{l}\text { Connolly } \\
\text { et al., } 2001\end{array}$ \\
\hline
\end{tabular}


Table 2. Summary of estimated and filmed velocities from archaeological experimental replication studies on spear thrusting.

\begin{tabular}{|c|c|c|c|c|c|}
\hline $\begin{array}{l}\text { Type } \\
\text { experiment }\end{array}$ & $\begin{array}{l}\text { Velocity } \\
\text { (range) }\end{array}$ & $\begin{array}{l}\text { Velocity } \\
\text { (mean) }\end{array}$ & $\begin{array}{l}\text { Estimated or } \\
\text { Filmed }\end{array}$ & Firing mechanism & Source \\
\hline $\begin{array}{l}\text { Controlled } \\
\text { Archaeological } \\
\text { Experiment }\end{array}$ & $\begin{array}{l}1.0-1.5 \\
\mathrm{~m} / \mathrm{s}\end{array}$ & $\mathrm{N} / \mathrm{A}$ & Estimated & $\begin{array}{l}\text { Crossbow } \\
28 \mathrm{~kg} \text { draw weight }\end{array}$ & $\begin{array}{l}\text { Shea et al., } \\
\text { 2002; 2001 }\end{array}$ \\
\hline $\begin{array}{l}\text { Controlled } \\
\text { Archaeological } \\
\text { Experiment }\end{array}$ & $\begin{array}{l}1.1-2.7 \\
\mathrm{~m} / \mathrm{s}\end{array}$ & $\begin{array}{l}\text { Not } \\
\text { reported }\end{array}$ & $\begin{array}{l}\text { Transient recorder, } \\
\text { light curtains }\end{array}$ & $\begin{array}{l}\text { Pendulum, swinging } \\
\text { metal arm with added } \\
\text { mass }\end{array}$ & $\begin{array}{l}\text { Iovita et al., } \\
2016\end{array}$ \\
\hline $\begin{array}{l}\text { Controlled } \\
\text { Archaeological } \\
\text { Experiment }\end{array}$ & $\begin{array}{l}7.8-10.3 \\
\mathrm{~m} / \mathrm{s}\end{array}$ & $\begin{array}{l}8.9 \\
\text { (untipped) } \\
9.4 \text { (tipped) } \\
(n=23)\end{array}$ & $\begin{array}{l}\text { Filmed } \\
\text { Bushnell Speedster } \\
\text { III radar gun }\end{array}$ & $\begin{array}{l}\text { Crossbow } \\
20 \mathrm{~kg} \text { draw weight }\end{array}$ & $\begin{array}{l}\text { Wilkins et al. } \\
\text { 2014a; 2014b }\end{array}$ \\
\hline
\end{tabular}

In response to these problems and the resulting need to develop a new experimental framework, the current paper describes the results from a human performance trial of 11 males trained in military bayoneting that was designed to record impact velocities and force profiles for two-handed spear thrusting. Trained males were chosen with the aim of evaluating the upper limits of performance because males produce significantly higher energies when stabbing than females (Horsfall et al., 1999), and with the further aim of evaluating the hypothesis that training improves performance in spear thrusting. The study was not designed to capture data on 'effectiveness' of these spears with respect to killing animals, though depth of penetration (DoP) in PermaGel ${ }^{\mathrm{TM}}$ (which is a muscle simulant) was recorded. Untipped wooden spears were chosen as they are the earliest implements identified as weapons in the archaeological record, are known to have been in use throughout the Pleistocene and Holocene (Adam, 1951; Clastres, 1972; Davidson, 1934; Davidson, 1936; Driver, 1939; Goodale, 1994; Luebbers, 1975; Moseley, 1877; Noetling, 1911; Oakley et al., 1977; Swanton, 1946; Stewart, 1947; Thieme, 1997), and provide a homogenous tip material and shape.

\section{Materials and Methods}

\subsection{Materials}

\subsubsection{Spear Replicas}

Spear replicas were designed to match published measurements for Spear II from the collection of wooden implements from Schöningen (Thieme 1999a 
p.470; Thieme 1999b p.389). Two spear shafts and three removable spear tips were used in this study; the shaft and tips were joined by a device consisting of aluminium caps containing a load cell, which is described in detail below. Measurements were made of all spear replicas including diameters at a number of points measured from the distal end of the spear, point of balance, mass of spear, and shape characteristics of the front $100 \mathrm{~mm}$ of the tips (Table 3). All measurements were within a millimeter of the measurements available for Schöningen Spear II (Table 3). Schöningen Spear II was chosen as it is a complete example with published measurement data available at the time of manufacture, and with measurements closest to mean values of the sample of published complete spears from Schöningen (Thieme 1999a). Although specific measurement data on the distal tips of the Schöningen spears were unavailable at the time the current study was conducted, the replica tips were designed according to the taper and size measured from scaled photographs of Spear II (Thieme 1999b, p.391). The slight difference in mass between the two replicas is due to slight variations internal to the wood.

Table 3. Measurement data for spear replicas (SR) compared with published measurement data on Schöningen Spear II at the time of replica manufacture.

\begin{tabular}{|c|c|c|c|c|c|c|c|c|}
\hline Spear & Length & $\begin{array}{l}\text { Dia. } \\
\text { at } \\
10 \\
\mathrm{~mm}\end{array}$ & $\begin{array}{l}\text { Dia. } \\
\text { at } \\
50 \\
\text { mm }\end{array}$ & $\begin{array}{l}\text { Dia. } \\
\text { at } \\
800 \\
\text { mm }\end{array}$ & $\begin{array}{l}\text { Dia. at } \\
1150 \mathrm{~mm} \\
\text { (midpoint) }\end{array}$ & $\begin{array}{l}\text { Dia. } \\
\text { at } \\
1530 \\
\text { mm }\end{array}$ & mass & $\begin{array}{l}\text { point of } \\
\text { balance* }\end{array}$ \\
\hline $\begin{array}{l}\text { Schöningen } \\
\text { Spear II† }\end{array}$ & 2300 & $\neq$ & $\neq$ & 37 & 35 & 34 & $\neq$ & $\neq$ \\
\hline SR1 & 2300 & 5 & 16 & 37 & 35 & 34 & 752 & 1080 \\
\hline SR2 & 2300 & 5 & 15 & 36 & 35 & 33 & 806 & 1095 \\
\hline
\end{tabular}

All measurements are in mm except mass, in grams. * Measurements are distances measured from distal end. + Measurement data from Thieme 1999b: 389 . $\neq$ Data not available at time of experiment.

Wood for the spear replicas was obtained from a stand of Norwegian spruce (Picea abies) that had been planted on limestone/clay soil in the mid 1980 s at Bedgebury Pinetum in Kent, England. The trees grew in natural forested conditions. The replicas were manufactured from spruce grown in warm conditions; therefore, trees with a circumference larger than necessary for the finished product were chosen. The use of the heartwood provided the use of higher density wood by avoiding the soft sapwood, as the Schöningen weapons 
were manufactured from dense slow-growing spruce (Schoch et al. 2015; Thieme 1997). Like the Schöningen spears, the distal ends of the spears were created from the hardest base of the trees (Thieme 1999b, p.391). Spear replicas were made within 3 months of cutting the trees, and as the current study was not designed to examine usewear and spear thrusting is not affected by aerodynamics, were made manually using metal tools.

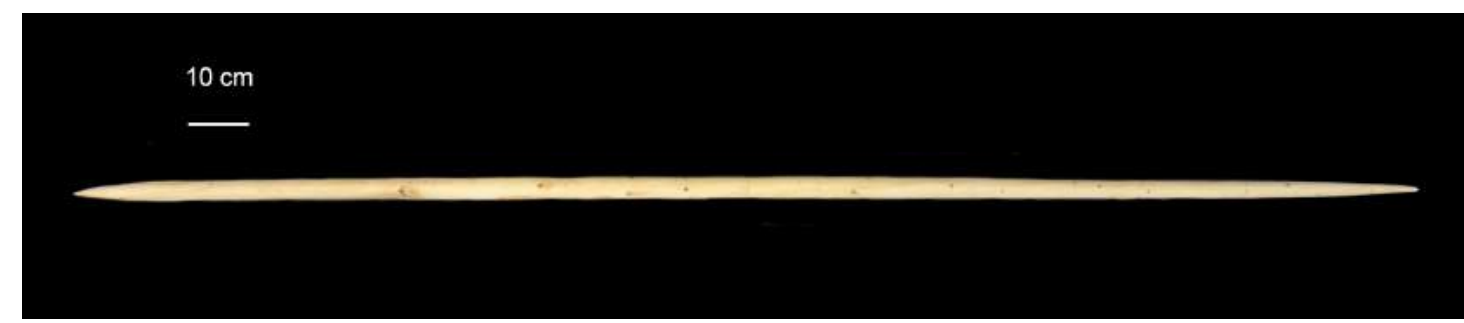

Figure 1. Replica of Schöningen Spear II. Scale is by distal end.

A load cell (Kistler; 1-Component Force Sensor 9031A, serial number 490937; maximum range $=60 \mathrm{KN}$ ) was mounted in a custom-made device fitted between the spear shaft and point; two aluminium caps fitted to the spear shaft and point, enclosing the load cell (Figure 2 and Figure 3) (Horsfall et al., 1999). The device measured $224 \mathrm{~mm}$ in length and weighed $452 \mathrm{~g}$. It is recognised that adding the mass of the load cell to the spears increased the total mass of the spears by a significant percentage (Table 3). However, the replicas' total masses of $1258 \mathrm{~g}$ (SR1) and $1204 \mathrm{~g}$ (SR2) fit comfortably within the range of masses of 55 ethnographic wooden spears, studied by one of the authors (AM) in museum collections in the UK (Horniman Museum; The Museum of Archaeology and Anthropology, Cambridge) and Australia (South Australian Museum, Adelaide; Australia Museum, Sydney; Tasmanian Museum and Art Gallery, Hobart) (Table 4). Palter (1977) provided mass data on Australian hand-thrown spears, with a range of $100 \mathrm{~g}$ to $1350 \mathrm{~g}$ (no mean provided). Oakley et al. (1977) hypothesised that thrusting spears are likely to be heavier than hand-thrown spears, though distinctions between these two delivery systems may not be discrete as hand-held spears might have served both functions depending upon context (Davidson, 1936 p.457; Guthrie, 2005; Hitchcock and Bleed, 1997 p. 348; Rots, 2009). Mass data provided in Oakley et al. (1977) for spears hypothesised to be thrusting weapons $(n=7)$ suggest a range of 283-1358 g, though their method for determining a thrusting 
function for that sample is unclear and therefore problematic. Although further research is ongoing on distinguishing between ethnographic handthrown and thrusting wooden spears, the spear replicas used in the current study, even with the added mass of the load cell, are within the ranges of ethnographic examples, albeit on the high side. This mass increase might slightly reduce impact velocity. Combined with the added mass of the load cell, the mass difference between the two spear replicas used only accounts for $4 \%$ additional mass of spear replica 2 and thus the variation in mass between the two replicas is unlikely to have affected results.

Table 4. Descriptive statistics of ethnographic spears studied.

\begin{tabular}{|llllll|}
\hline Mean & Median & SD & Minimum & Maximum & n \\
775.6 & 750 & 387.84 & 150 & 2246 & 55 \\
\hline
\end{tabular}

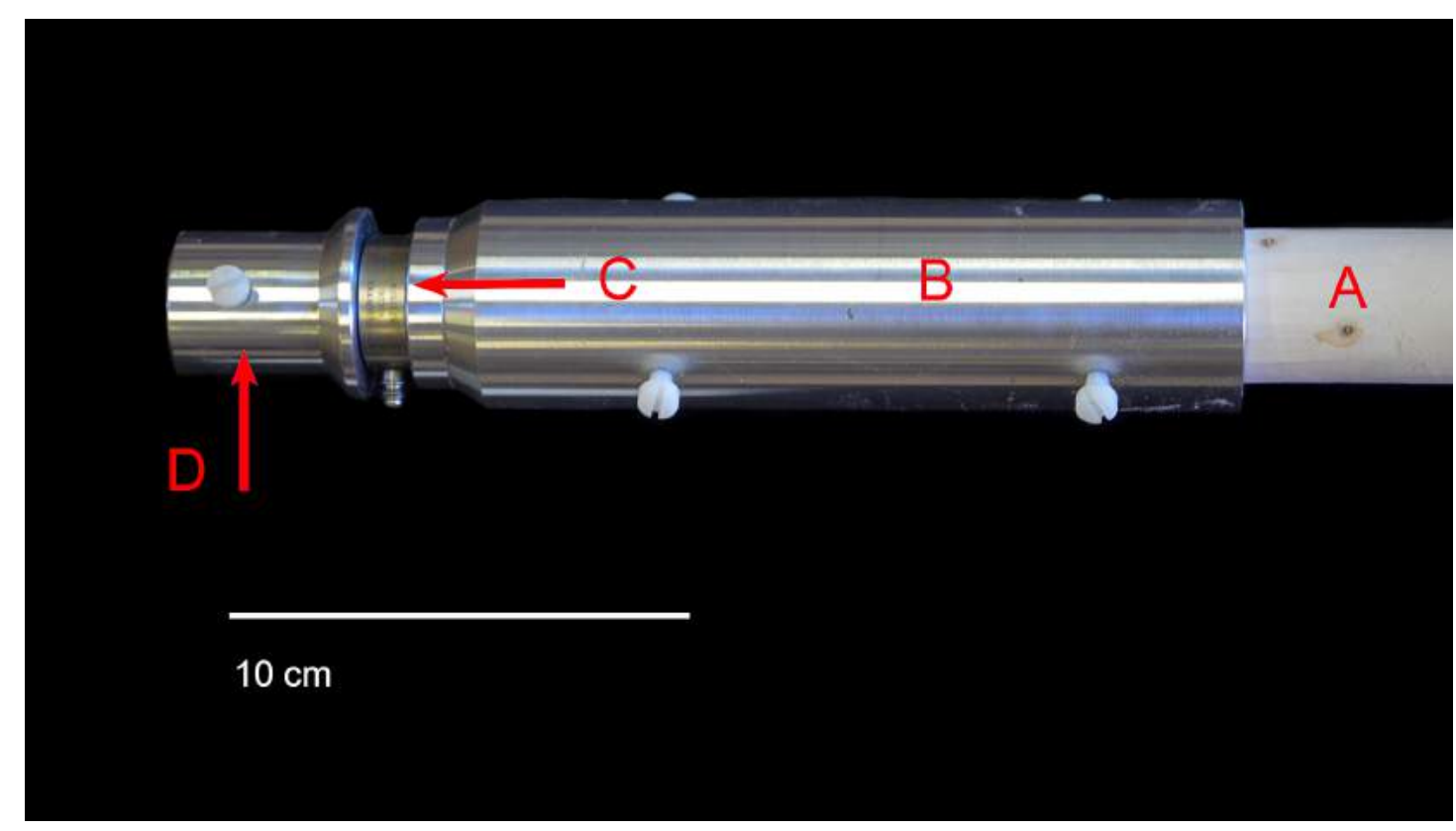

Figure 2. Load cell mounted on a spear shaft. $(A=$ spear shaft, $B=$ custom made mount, $C$ = load cell, $\mathrm{D}=$ spear point mount). 


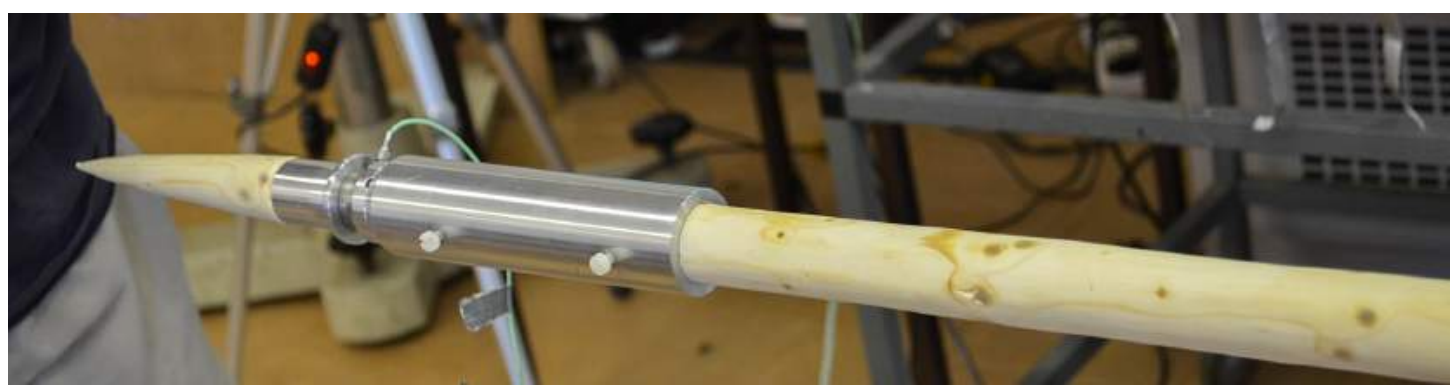

Figure 3. Spear replica with custom-fitted load cell.

Casts were made of all the spear tips from $100 \mathrm{~mm}$ the from distal tip of each spear replica. Moulds of the spear tips were made using a high quality silicone moulding agent (Prevest DenProß Hiflex Putty) and casts were made using a liquid polyurethane resin (Prevest DenPro® EasyFlo 6o) (Figure 4). To compare the relative pointedness of the spear tips, a guided free-fall impact test was designed and performed for the casts made from the 3 tips used in the spear thrusting trial. A two-metre long plastic pipe with a $30 \mathrm{~mm}$ diameter opening was used for the impact drop test. Holes were drilled along the pipe to reduce air resistance during impact testing and a level was used to ensure the pipe was vertical. A metal bar (150 g) was attached to the rear of each cast in order to ensure adequate kinetic energy upon impact, and a small amount of plastiline was added if necessary to ensure that each cast and bar combined weighed exactly 175 grams. The points were then dropped from $2.21 \mathrm{~m}$ down the tube into a block of plastiline sculpting compound (softness 50) at an air temperature of $16^{\circ} \mathrm{C}$. Each cast was dropped 10 times, measuring the depth of penetration (DoP) to the nearest $\mathrm{mm}$ for each drop into the plastiline. The purpose of this test was to confirm that slight variations in each spear tip's morphology did not greatly affect results of the human performance spear thrusting experiment. 


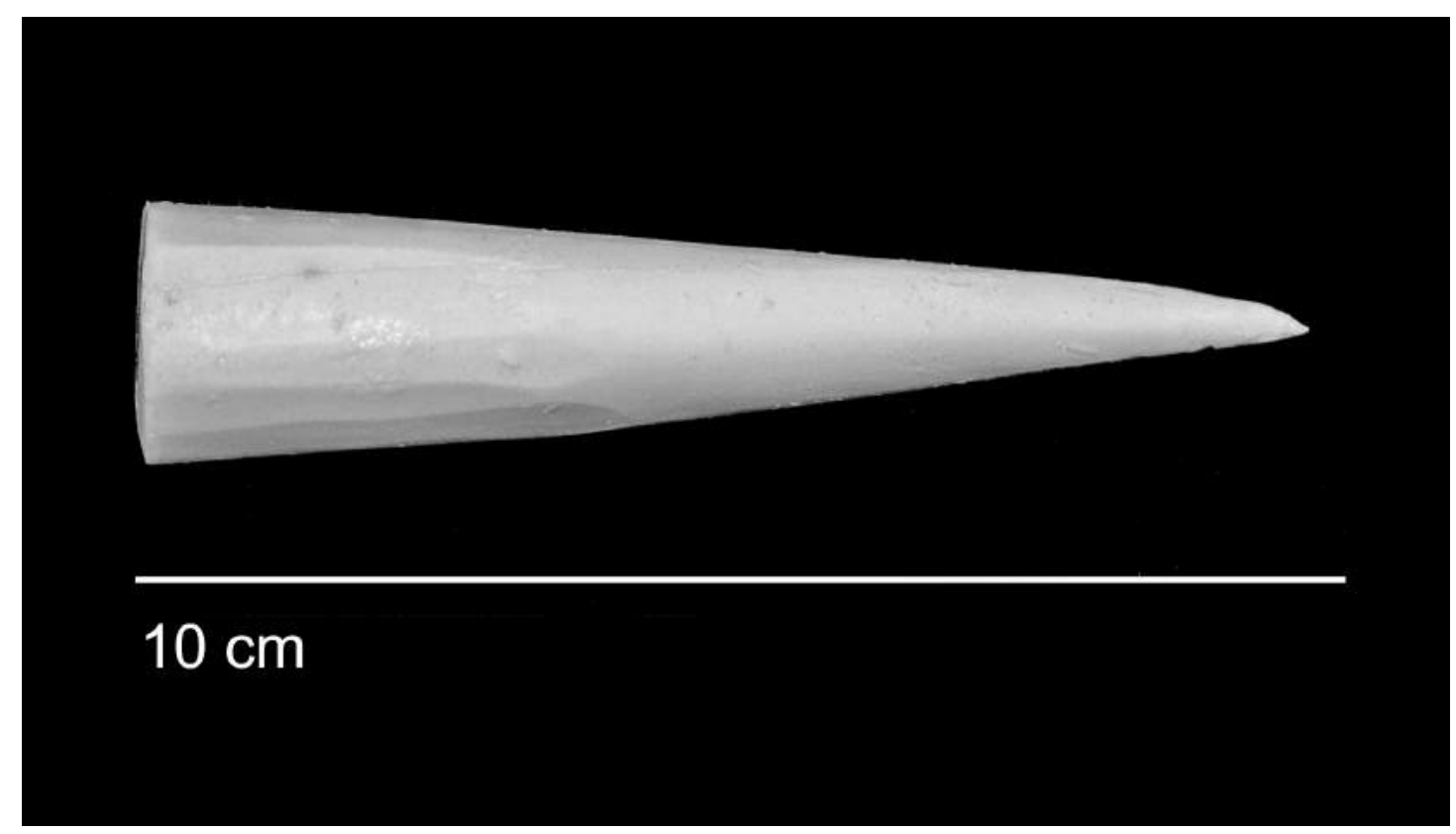

Figure 4. One of the resin casts of a spear point for use in impact tests.

\subsubsection{Target}

As this was a study designed to understand the interaction between human performance in spear thrusting and wooden spears, a homogenous target was preferable for experimental control. Targets consisted of 3 blocks of PermaGel ${ }^{\mathrm{TM}}$ measuring $440 \mathrm{~mm}$ x $290 \mathrm{~mm}$ x $130 \mathrm{~mm}$, weighing $13 \mathrm{~kg}$ each. PermaGel $^{\mathrm{TM}}$ is a muscle simulant used in ballistic testing and approximates the performance of 10\% (by mass) gelatine (Mabbott et al., 2013). PermaGel ${ }^{\mathrm{TM}}$ is a translucent, reusable, synthetic material that does not require temperature conditioning (as gelatine does) (Figure 5). One major advantage of using PermaGel ${ }^{\mathrm{TM}}$ is the ability to clearly identify wound tracks, facilitating subsequent thrust placements as well as filming (Figure 6). PermaGel ${ }^{\text {TM }}$ has previously been used as a tissue simulant in sharp weapon studies (Cowper et al., 2016; 2015). 


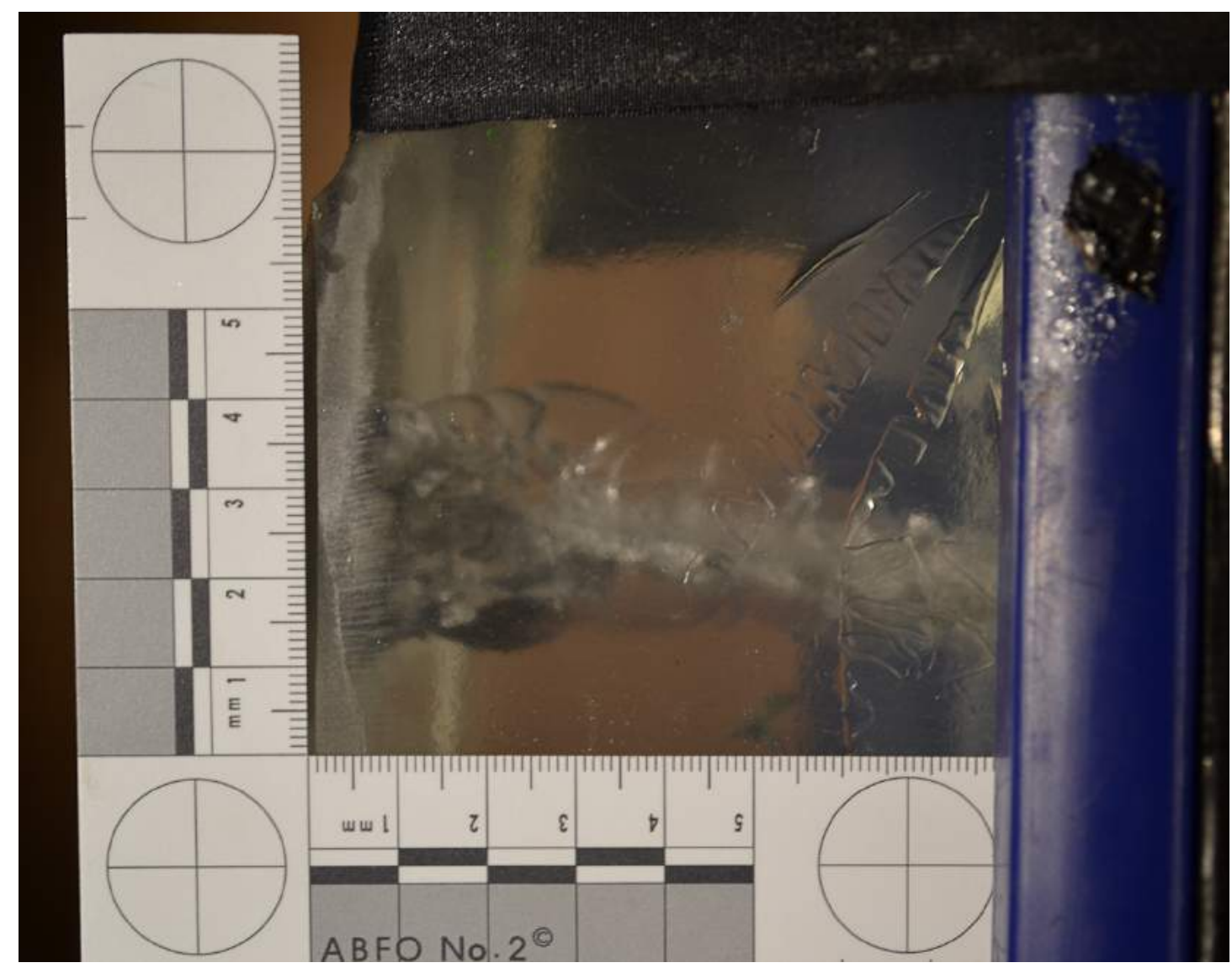

Figure 5. Block of used PermaGelTM displaying spear thrust 'wound' track.

\subsubsection{Human Participants}

Eleven male participants, recruited from the military staff at the Defence Academy of the United Kingdom (Shrivenham, Oxon, UK) volunteered to take part in the trial (July 22, 2014). Ethical approval was obtained from the Science and Engineering Research Ethics Committee of Cranfield University, Shrivenham, UK (approval number 004_2013). Participants were orally briefed, provided signed informed consent and were aware they could withdraw at any stage of the work without penalty. Participants were not allowed a practice thrust and were not paid. All participants had received training in bayonet use (two-handed thrusting with a sharp weapon), as part of their military training. Each participant performed at least 3 thrust impacts taking approximately 10 minutes total. The participant sample size and number of stabs per participant per type compares favourably with several stabbing studies (e.g. Cowper et al., 2015; Horsfall et al., 2005; Kemp et al., 2009; Miller and Jones, 1996) and is an improvement on spear thrusting 
studies (Connolly et al., 2001; Schmitt et al., 2003). Self-reported masses of participants ranged from $61 \mathrm{~kg}-100 \mathrm{~kg}$ (mean=81.2 kg; $\mathrm{SD}=10.3 \mathrm{~kg}$ ), and selfreported heights were $1.68 \mathrm{~m}-1.95 \mathrm{~m}$ (mean=176.8 m; SD=7.7 kg) ${ }^{1}$. The mean body mass and height of the participants correspond well with estimates for H. heidelbergensis ( Froehle et al., 2013; Stringer et al., 1998; Trinkaus et al., 1999).

\subsection{Methods}

\subsubsection{Experimental data collection}

Participants were not coached on spear hold or stance, and were asked to thrust the spear into a PermaGel ${ }^{\mathrm{TM}}$ target with maximum force. Two participants, upon producing unusual force profiles, were coached on technique to investigate whether this influenced force profiles. Participants stood behind a foot plate, and thrusts were from a standing position without approaching the target (Figure 6). Participants were asked to avoid previous thrust areas into the PermaGel ${ }^{\mathrm{TM}}$. They were requested to perform a 'strike hold', in other words, thrusting the spear into the target with maximum force and then holding the spear in the target until DoP of the spear point into the PermaGel ${ }^{\mathrm{TM}}$ was measured (in $\mathrm{mm}$ ) using a calibrated ruler.

\footnotetext{
${ }^{1}$ In order to preserve the identity of the participants of this relatively small cohort, and in accordance with data sharing requirements, raw data on individual heights and weights is not provided.
} 


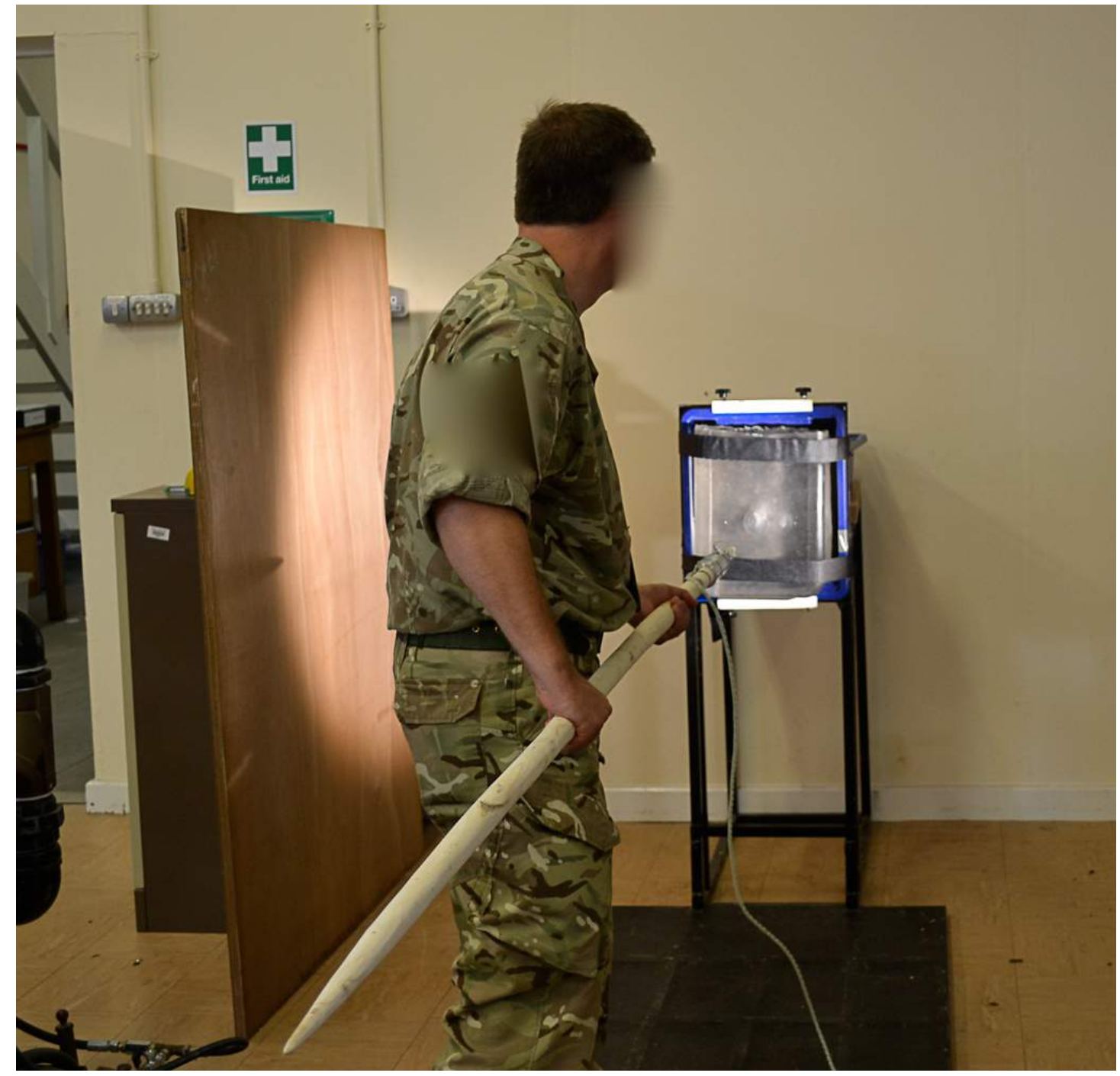

Figure 6: Participant performing spear thrusting in a block of PermaGel ${ }^{\text {TM }}$. Hand position was the most typical used by participants.

The load cell was connected to a data acquisition system (Figure 7) and the force $(\mathrm{N})$ and time (ms) profile of the impact event was captured using Imatek Impact Analysis (version 3.3.7) (maximum recording time $=100 \mathrm{~ms} ; 8000$ data points were collected). Every impact event was recorded using a Phantom V7 high-speed video camera (1000 fps) allowing velocity to be calculated using Phantom 675.2, software. A sample video is included as a supplementary file. 


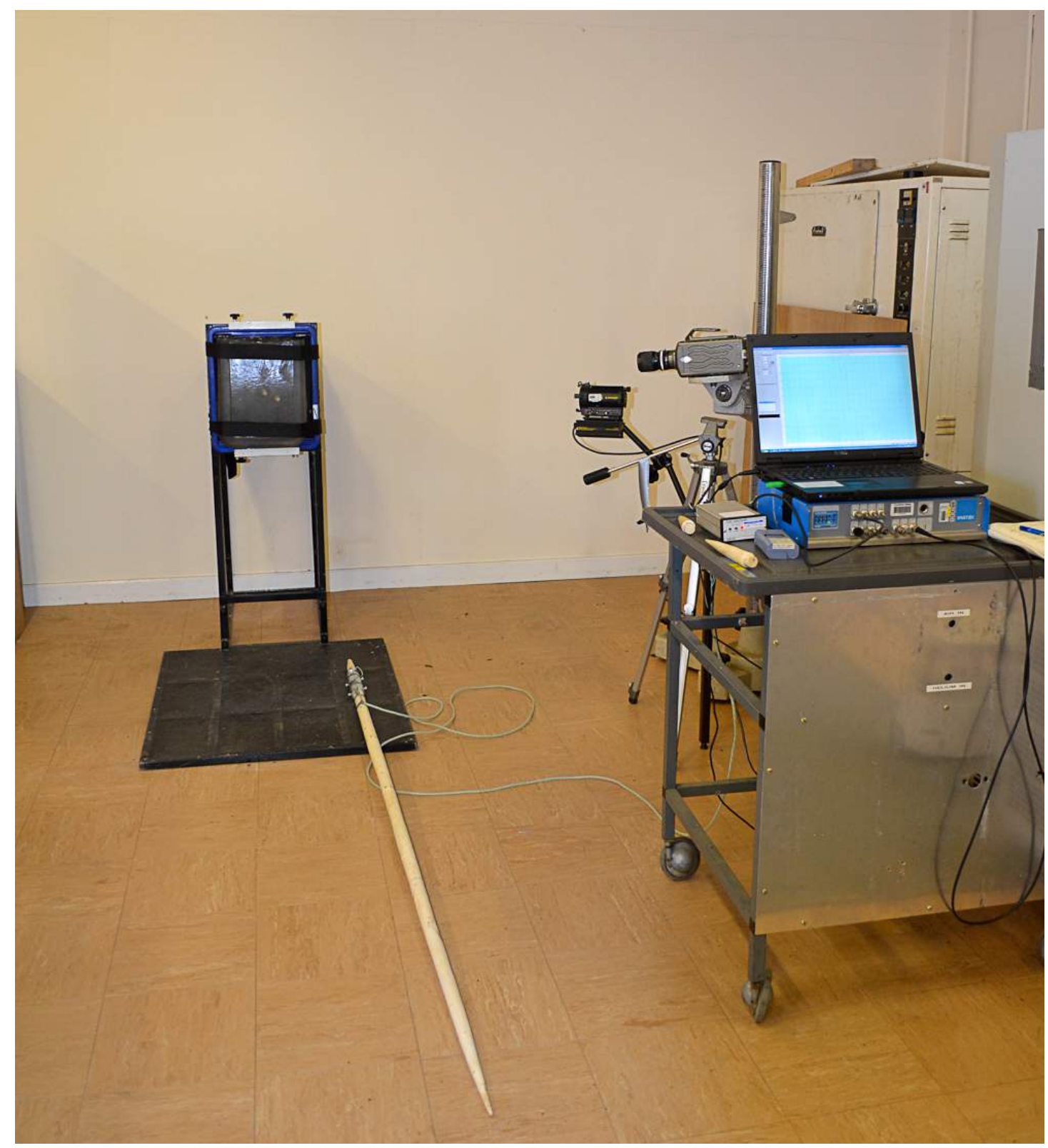

Figure 7. Experiment setup showing spear, PermaGelTM block, data acquisition and high speed video camera.

\subsubsection{Data analysis}

High speed video analysis was conducted using the software package Phantom Cine Viewer v2.5.744.0. All the videos were analysed by the same individual (AM) to minimise variation in technique. Impact was defined as the high speed video frame in which the spear first interacted with the PermaGel ${ }^{\mathrm{TM}}$ block and was considered to be frame $=0$. Impact velocity was defined as the mean velocity calculated from frames -2 to -22 before impact (

Figure 8). All statistics were calculated using the software package SPSS version 22. Force/time profiles were produced in Excel version 12.3.6. 


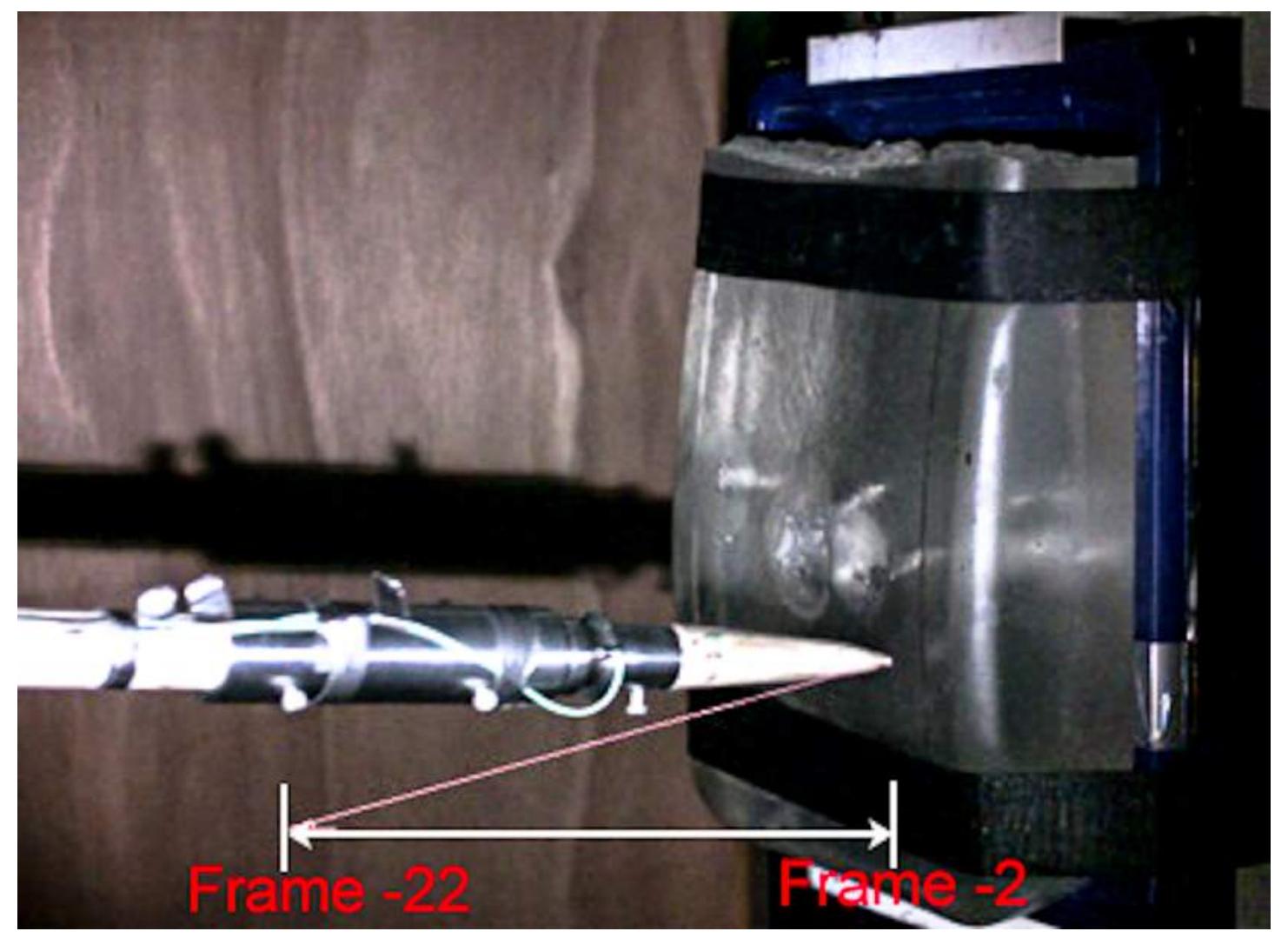

Figure 8. Still frame demonstrating high speed video analysis. The pink line shows the distance traveled from the beginning of the analysis (Frame -22) to 2 frames before impact with the target.

\section{Results}

Thirty-nine stab events were recorded, capturing force (Newtons) and impact velocity (meters per second, $\mathrm{m} / \mathrm{s}$ ). One video was unsuitable for analysis, due to the video containing fewer than 22 frames before impact, leaving a sample of thirty-eight videos for velocity results.

\subsection{Spear replicas}

The first shaft, spear replica 1 (SR1), broke after 22 stab events, and was thereafter replaced with SR2. SR1 broke in the front half of the spear at a point where several knots conjoined in the wood (ca. $1000 \mathrm{~mm}$ from distal end), forming a point of weakness in the wood. Possibly this weakness led to the spear breaking. 
Table 5 presents the results of the impact drop tests of the spear tip casts. The mean DoP into the plastiline block, measured to the nearest millimetre, had little variation from point to point. A Shapiro-Wilk test ( $\mathrm{p}>.05)$, a visual inspection of the skewness and kurtosis measures and standard errors, as well as a visual inspection of the histograms, normal Q-Q plots and box plots showed that the data were not normally distributed. A nonparametric Levene's test was used to verify the equality of variances in the samples (homogeneity of variance, $p=1.000$ ). Therefore there is an equality of variance in DoP into the plastiline by each spear tip. Thus interchanging the spear tips in the human thrusting experiment had a negligible impact on DoP into the PermaGel ${ }^{\mathrm{TM}}$ (measured to the nearest millimetre).

Table 5. Results of the impact drop tests.

\begin{tabular}{|c|c|c|c|c|c|}
\hline $\begin{array}{l}\text { Spear tip cast ID } \\
\text { number }\end{array}$ & $\begin{array}{l}\text { mean } \\
\text { DoP* } \\
(\mathrm{mm})\end{array}$ & $\begin{array}{l}\text { minimum } \\
\text { DoP } \\
(\mathrm{mm})\end{array}$ & $\begin{array}{l}\text { maximum } \\
\text { DoP } \\
(\mathrm{mm})\end{array}$ & $\begin{array}{l}\text { Standard } \\
\text { Deviation }\end{array}$ & $n$ \\
\hline 1 & 22.9 & 22 & 24 & 0.74 & 10 \\
\hline 2 & 23.9 & 23 & 25 & 0.74 & 10 \\
\hline 3 & 22.8 & 22 & 24 & 0.79 & 10 \\
\hline
\end{tabular}

\subsection{Depth of Penetration into PermaGel ${ }^{T M}$}

Depth of penetration was measured as a means of further understanding the interaction of impact velocities and forces (Table 6). The spear thrusts frequently impacted into the foam backing behind the PermaGel ${ }^{\mathrm{TM}}$. This study did not include bone or hide simulants as a homogenous target was desirable for experimental control to capture human performance, and the study was not designed to understand the 'effectiveness' of these spears on targets.

Table 6. Descriptive Statistics for Depth of Penetration (mm).

\begin{tabular}{|lllll|}
\hline Mean & SD & Minimum & Maximum & $\mathbf{n}$ \\
119.4 & 13.0 & 93 & 145 & 39 \\
\hline
\end{tabular}

\subsection{Participants}

Participants were a mix of right-handed $(n=8)$, and left-handed $(n=3)$. All but one chose their dominant hand as the trailing limb; Participant 6 used the 
right hand as the trailing limb. Upon questioning, the participant responded that this choice was due to training to use a bayonet right-handed regardless of handedness. Handholds, recorded as overhand or underhand for each participant varied more widely but never changed within a participant's series of stabs. Variations included overhand for trailing limb and underhand for leading limb (n=9) (Figure 6), underhand for trailing limb and overhand for leading limb $(\mathrm{n}=1)$, and overhand for both trailing and leading limbs $(\mathrm{n}=1)$. The impact event associated with the highest peak force involved one of the unusual handholds (underhand for trailing limb, overhand for leading limb). Location of hands on the shaft varied, with some participants changing this between replicates (e.g. P8).

\subsection{Impact Velocity}

Impact velocities ranged from $2.80-6.26 \mathrm{~m} / \mathrm{s},($ mean $=4.650 \mathrm{~m} / \mathrm{s}, \mathrm{SD}=0.748 \mathrm{~m} / \mathrm{s})($ Table 7). A histogram of the dataset (

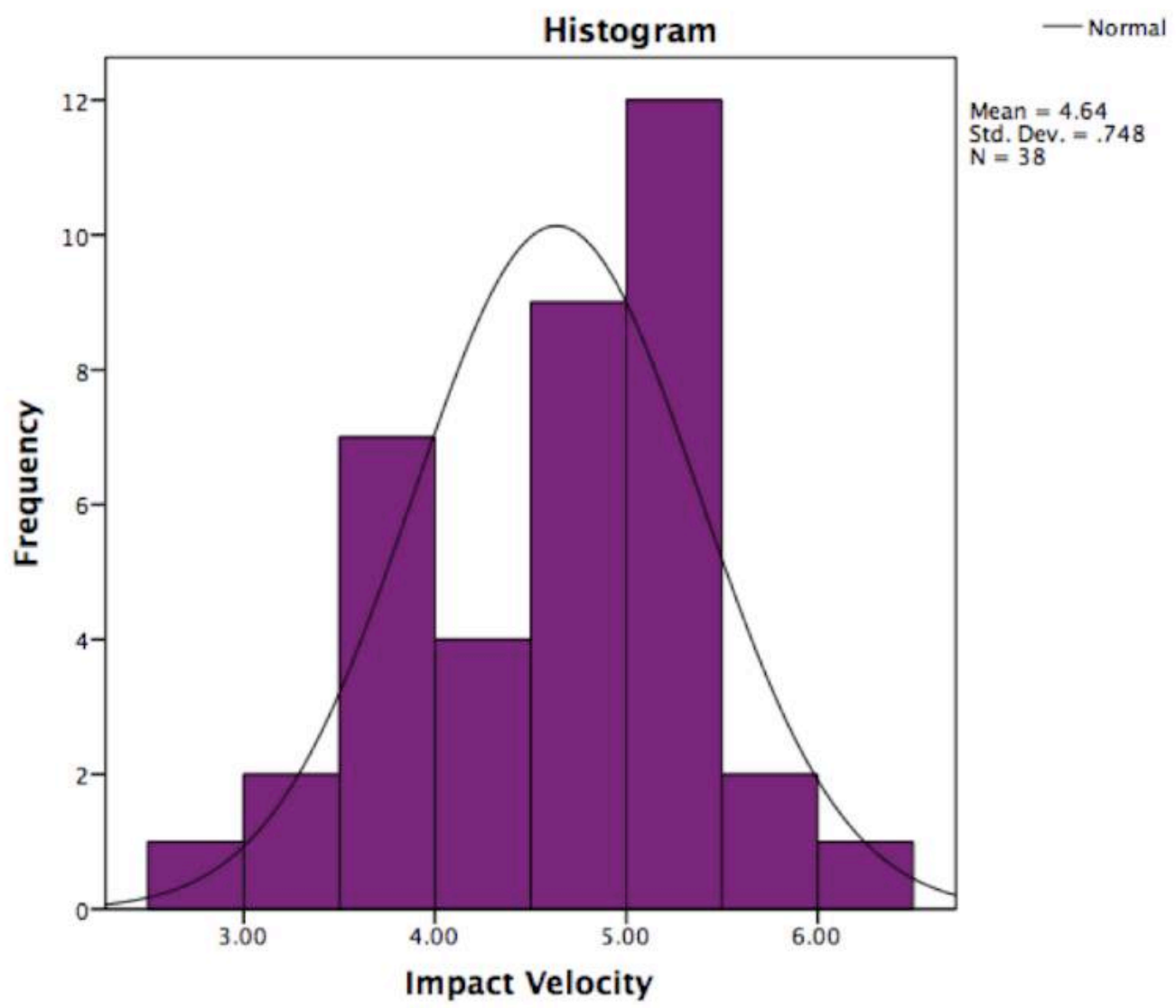

Figure 10) shows a bimodal distribution, and so normality tests were conducted, using the Shapiro-Wilk test as it is suitable for small sample sizes. 
The velocity dataset had a $p$-value of 0.627 confirming a normal distribution. The boxplot in Figure 12 shows impact velocities achieved by each participant.

Table 7. Descriptive Statistics for Impact Velocities (m/s).

\begin{tabular}{|lllll|}
\hline Mean & StDev & Minimum & Maximum & $\mathbf{n}$ \\
4.650 & .748 & 2.80 & 6.26 & 38 \\
\hline
\end{tabular}

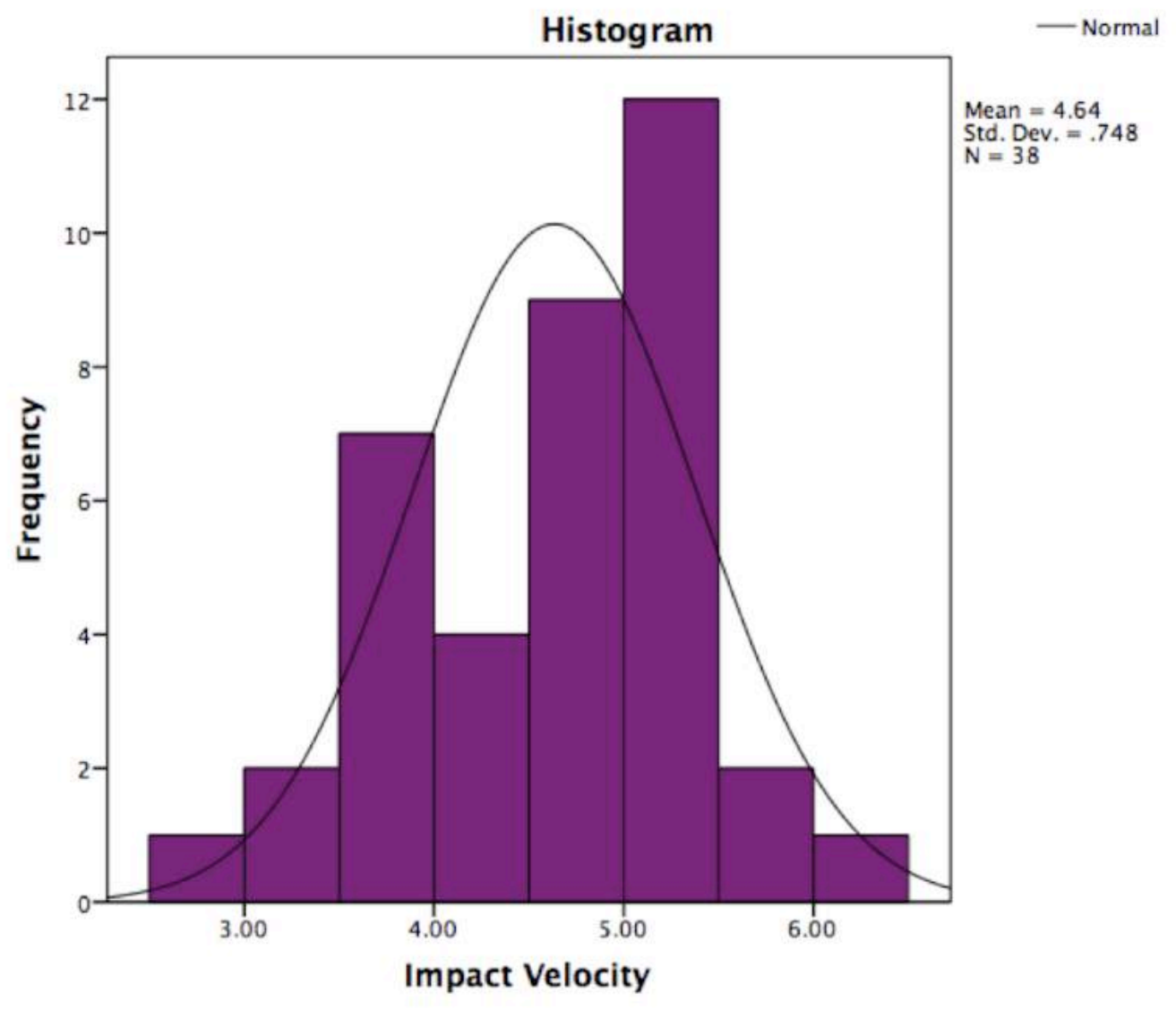

Figure 10. Histogram of the frequency distribution of impact velocities $(\mathrm{m} / \mathrm{s})$. 


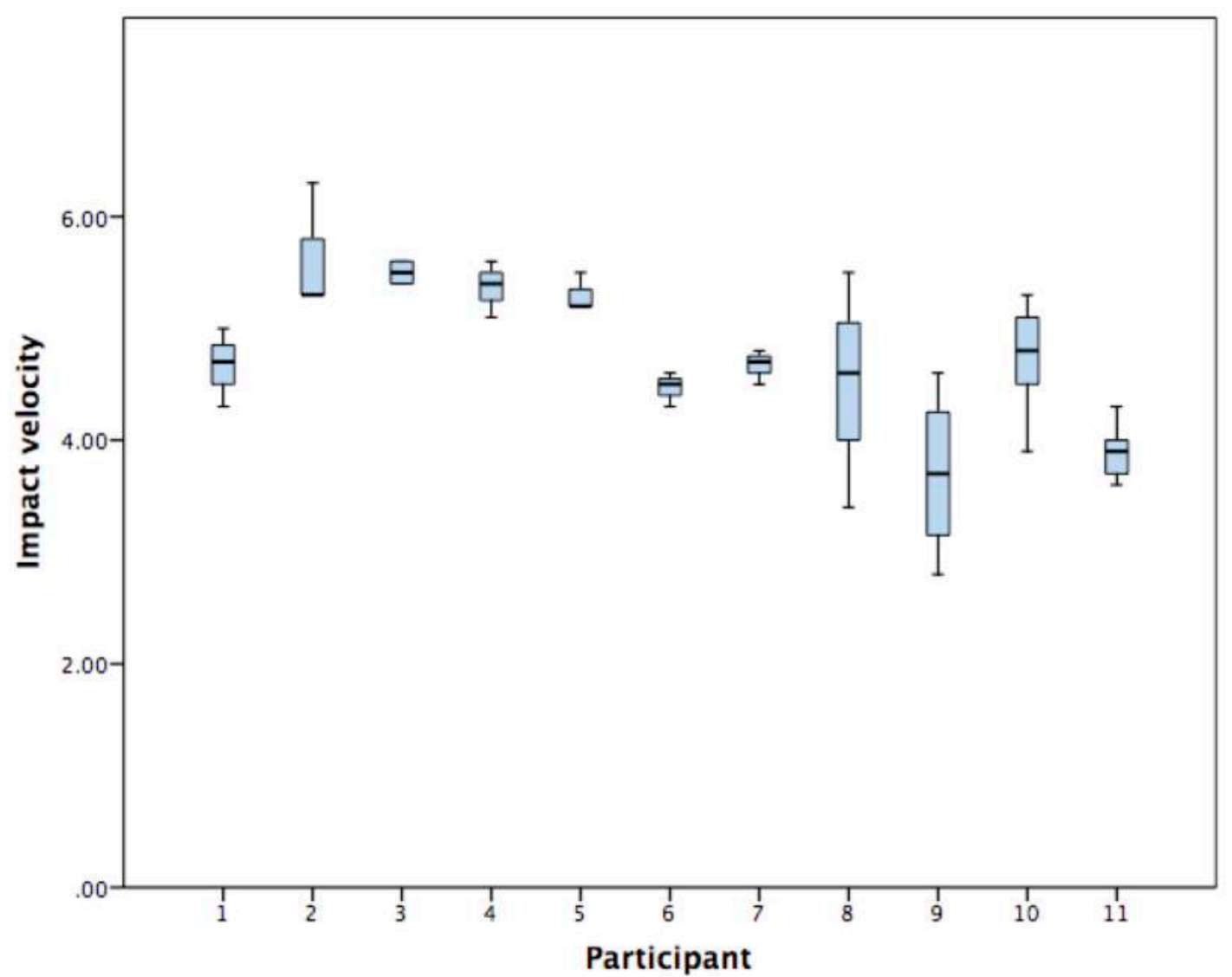

Figure 12. Boxplot of the impact velocities by participant.

\subsection{Force}

Peak forces ranged from 362-1120 N, (mean=661.o N; $\mathrm{SD}=186.2 \mathrm{~N})$ (Table 8).

A histogram of the data obtained showed a bimodal distribution (Figure 13).

The Shapiro-Wilk test had a $p$-value of 0.056 confirming a normal distribution. The boxplot in Figure 14 shows peak forces achieved by participant.

Table 8. Descriptive statistics for peak forces (N).

\begin{tabular}{|lllll|}
\hline Mean & SD & Minimum & Maximum & n \\
\hline 661.4 & $\mathbf{1 8 6 . 2}$ & 362 & 1120 & 39 \\
\hline
\end{tabular}




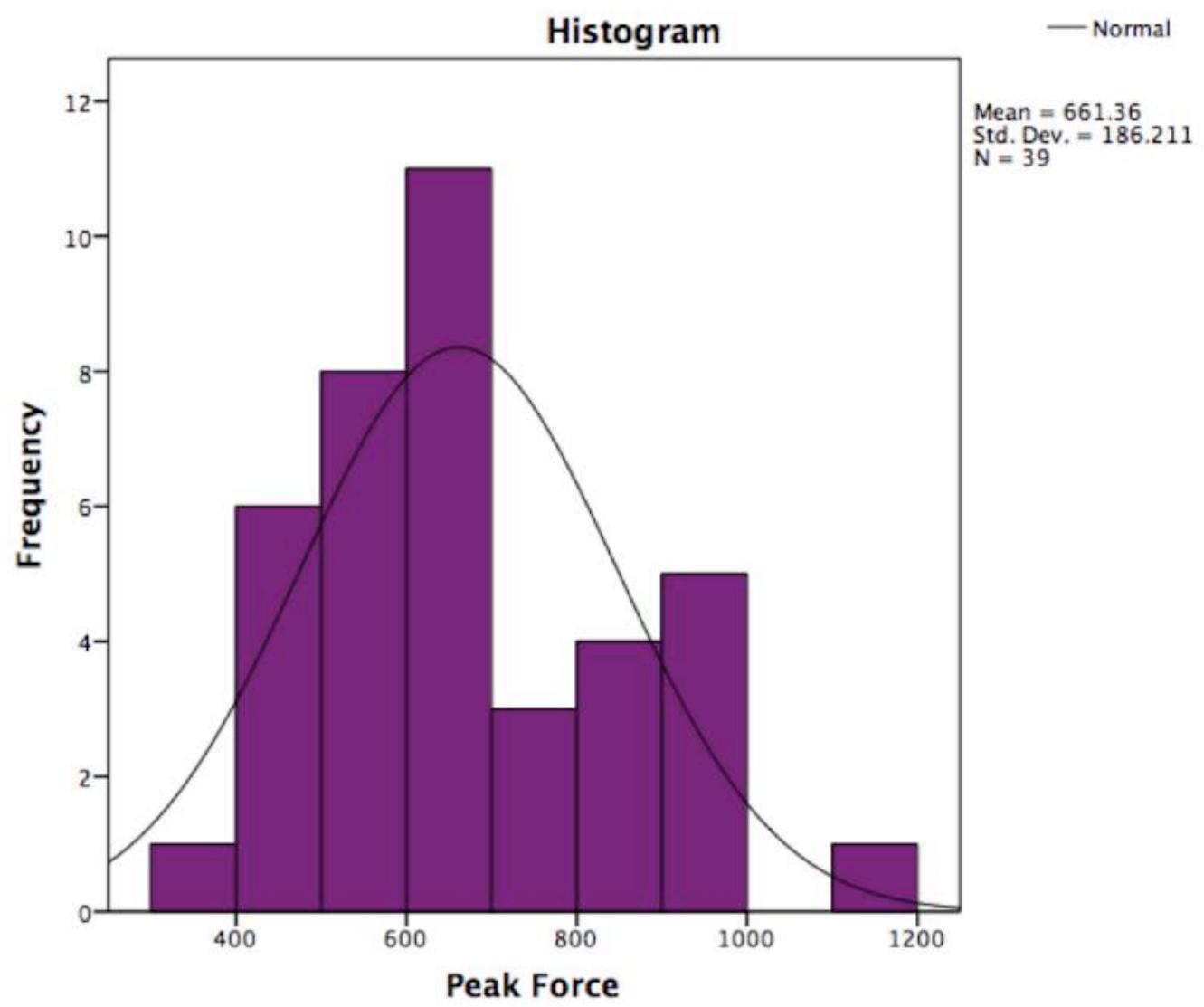

Figure 13. Histogram of the frequency distribution of peak force achieved per thrust.

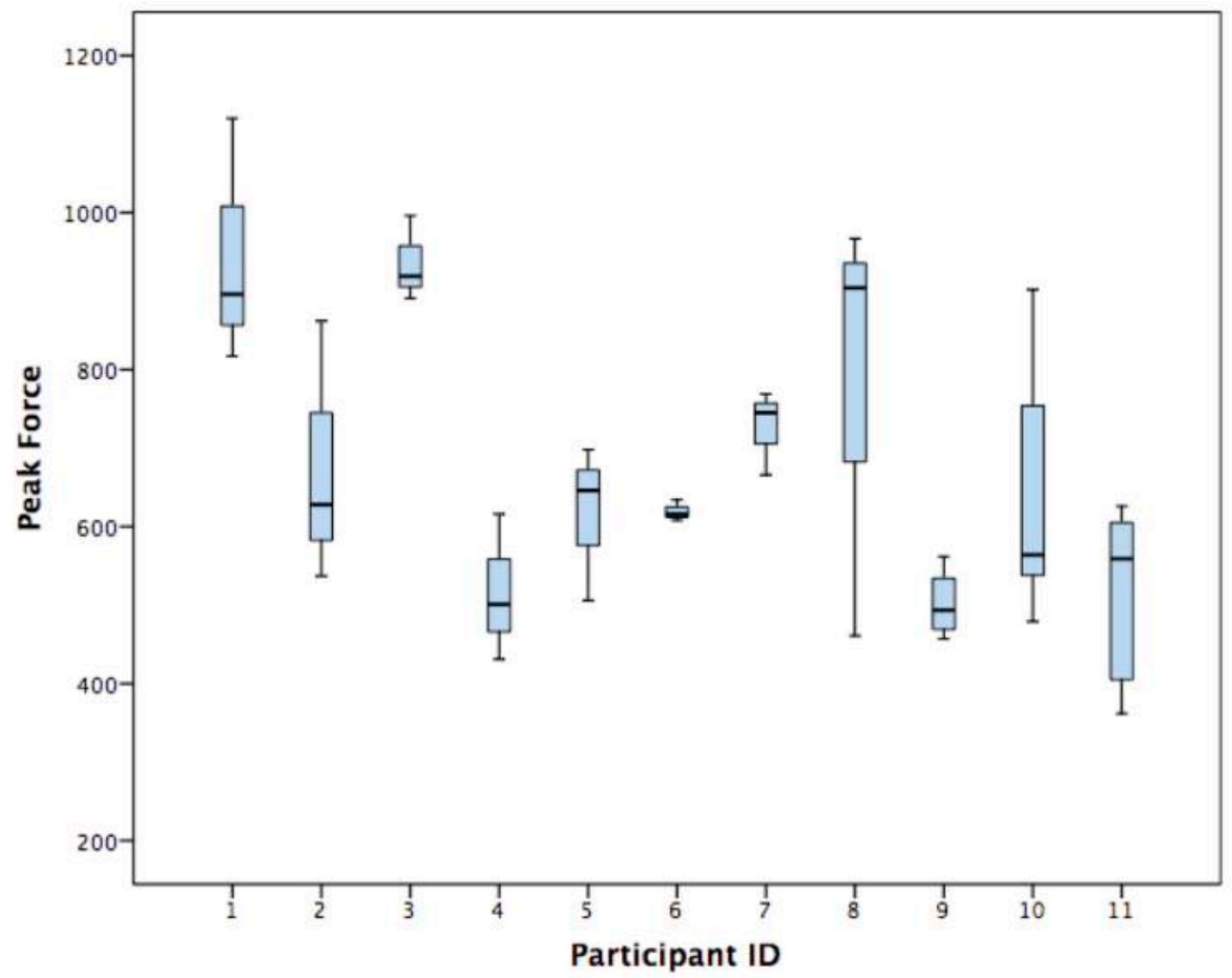

Figure 14. Boxplot of the peak force achieved per thrust by participant. 
Each spear thrust recorded force over time; selected force-time profiles are presented and discussed. Generalised categories of thrust profiles were created and designated as 'single peak', 'double peak', or 'push' to facilitate discussion of thrusting techniques. Typical force profiles $(n=29)$ show a single peak force followed by a tail as the spear was held in the target for the purpose of measuring DoP (e.g. Figure 15). A more unusual profile $(n=3)$ involved a double peak, where there are two peaks roughly similar in force (e.g.

\section{P1_1 Thrusting Force Profile}

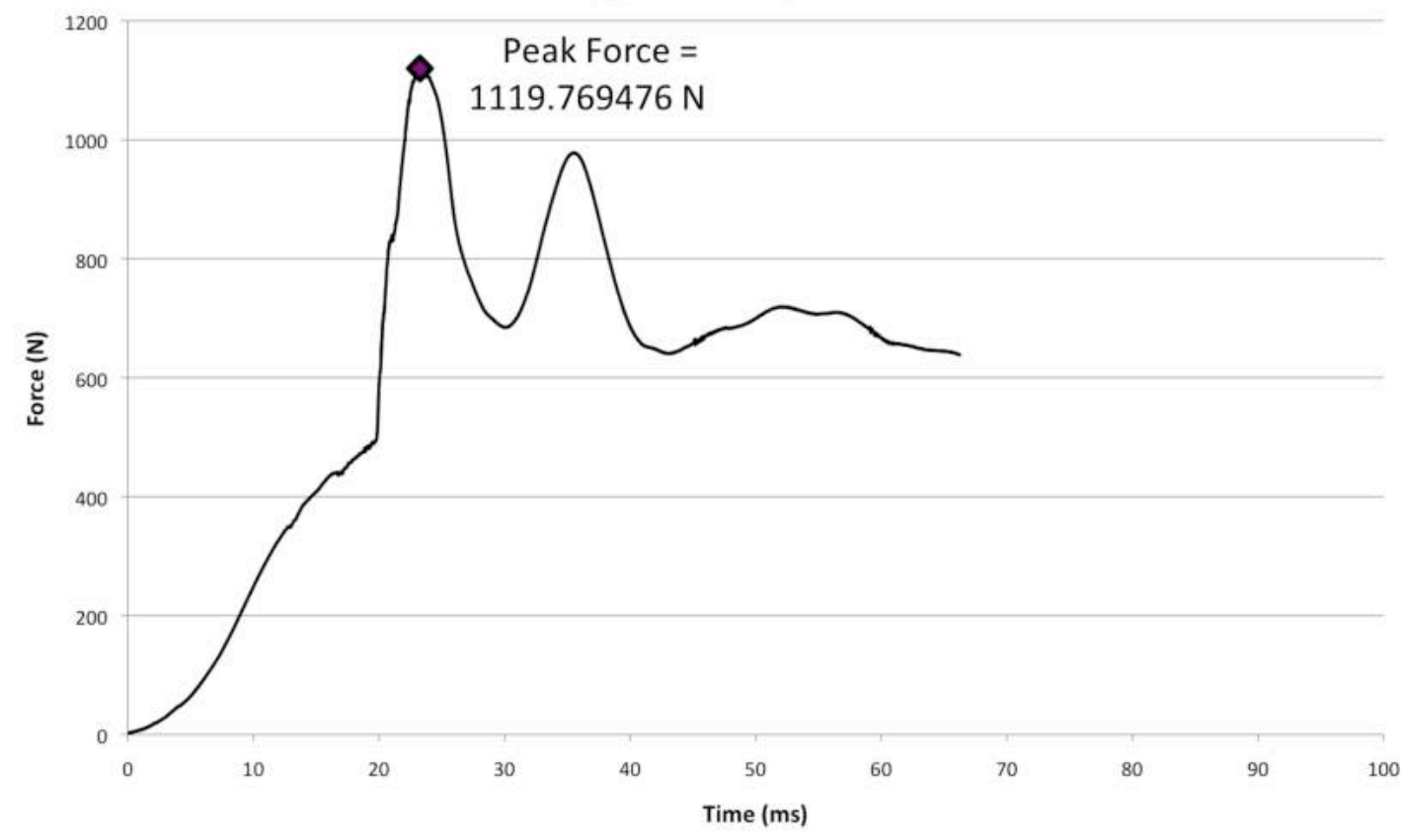

Figure 16). There were a number of 'push' force profiles in the dataset $(n=7)$, where a participant pushed their body mass into the target, achieving peak force at the end of the thrust (e.g.

P9_3 Thrusting Force Profile

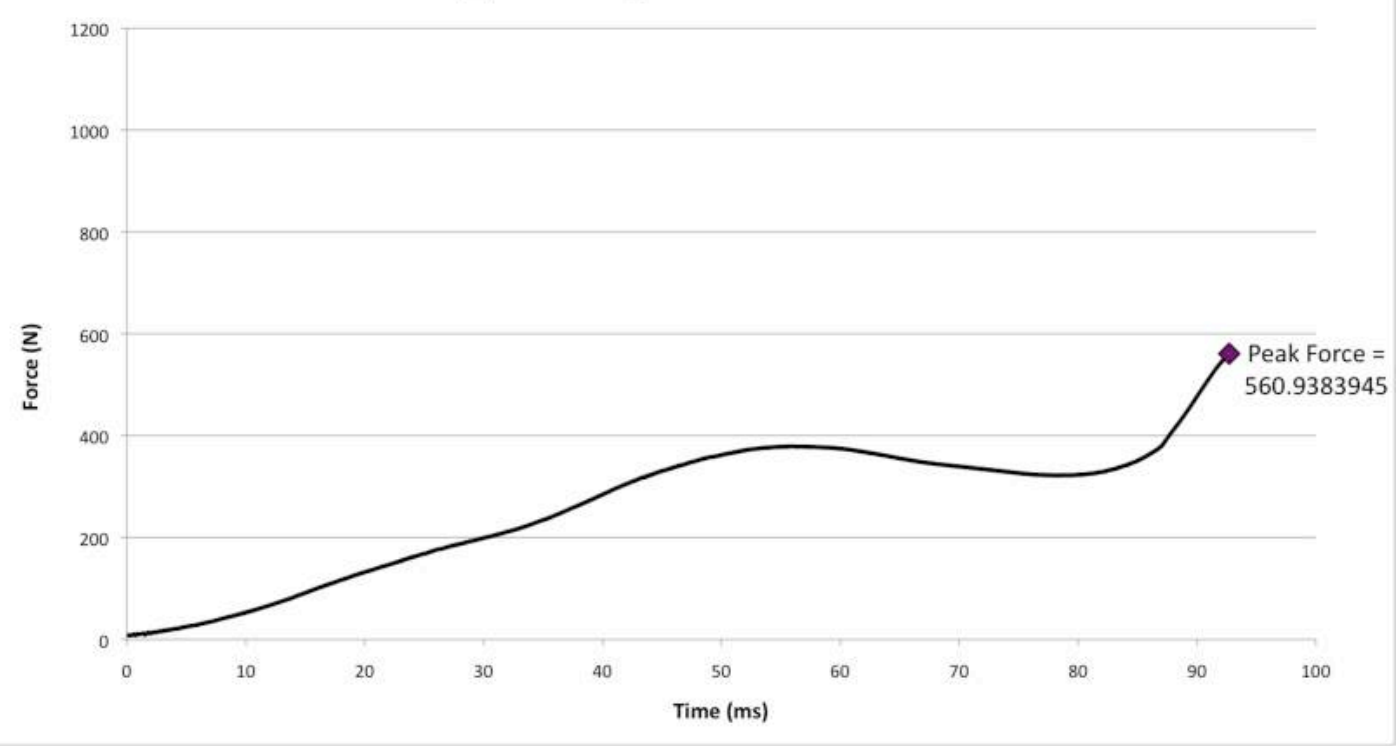

Figure 18). Overall these profiles clustered by individual, and upon analysis of the force profiles and discussion, individuals (e.g. P10 and P11) were able to 
change their technique to produce a different profile. P9 produced two 'singlepeak' profiles, followed by a 'push' profile, and a further 'single peak' thrust. P1o first produced two 'single-peak' profiles, replicates 3 and 4 were 'push' profiles, and after discussion, produced a further 'single-peak' profile. P11 first produced 3 'push' profiles, and subsequently was able to produce two 'single peak' profiles and one further 'push'. All three 'double peak' profiles were produced by $\mathrm{P} 1$, who also produced the highest peak force value of all the participants (P1_1). Although the sample of 'push' profiles is small $(n=7)$ an important observation is that all 3 participants who used this technique produced their highest individual force profiles with it (P9_3, P10_3, P11_2), with one of these (P10_3) producing a relatively high peak force.

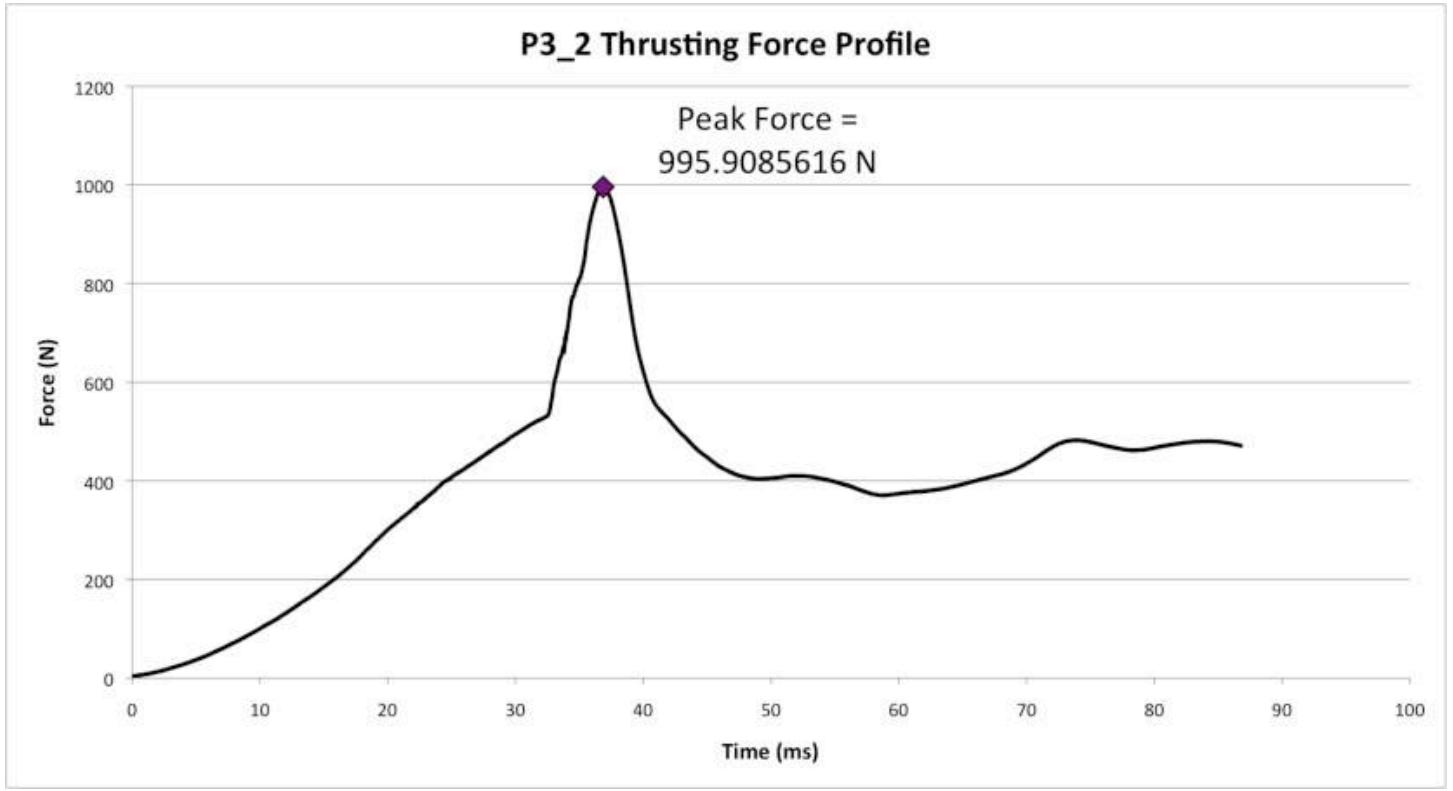

Figure 15. Example of a 'single peak' force-time profile (participant 3, replicate 2). 


\section{P1_1 Thrusting Force Profile}

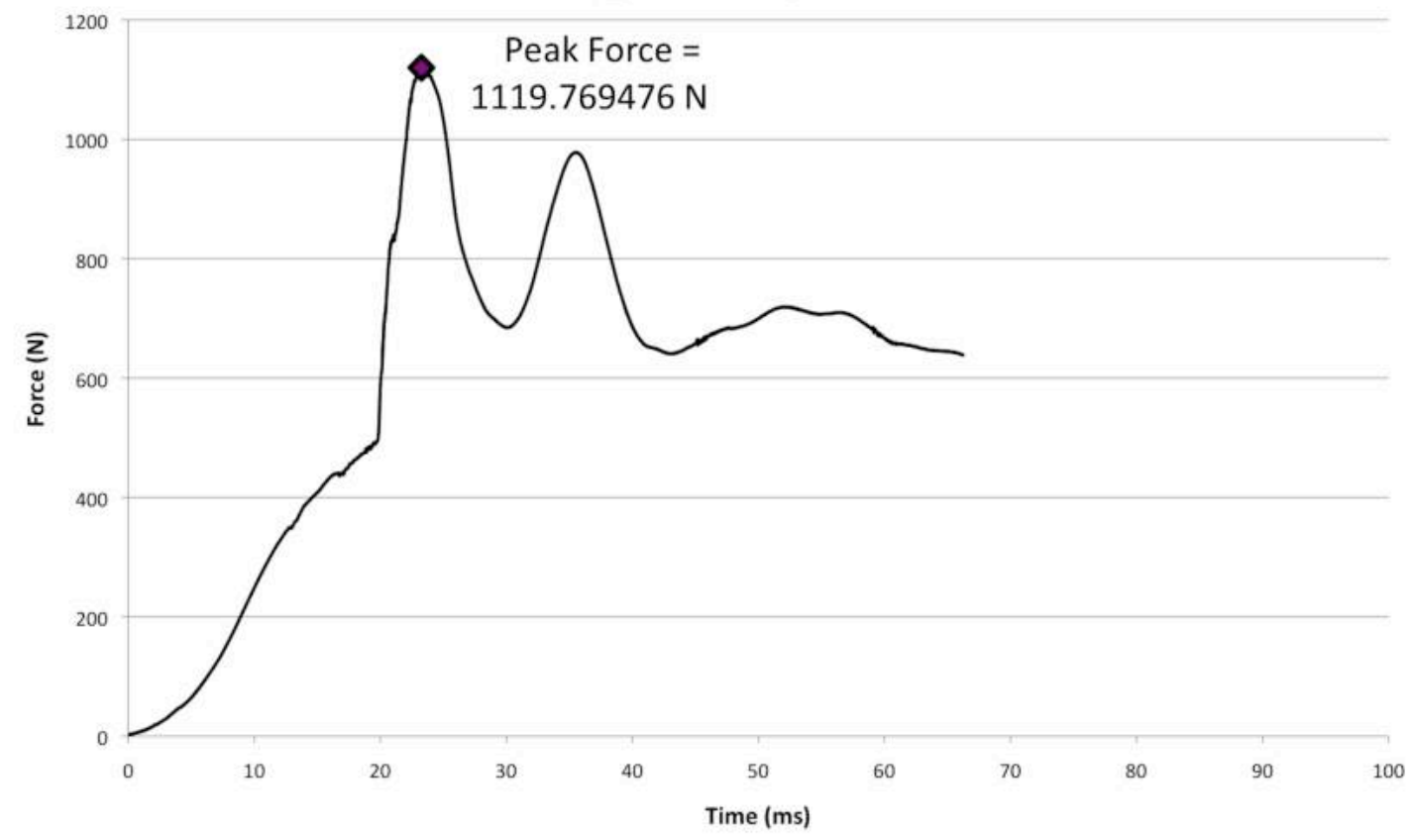

Figure 16. Example of a 'double peak' force-time profile (participant 1, replicate 1).

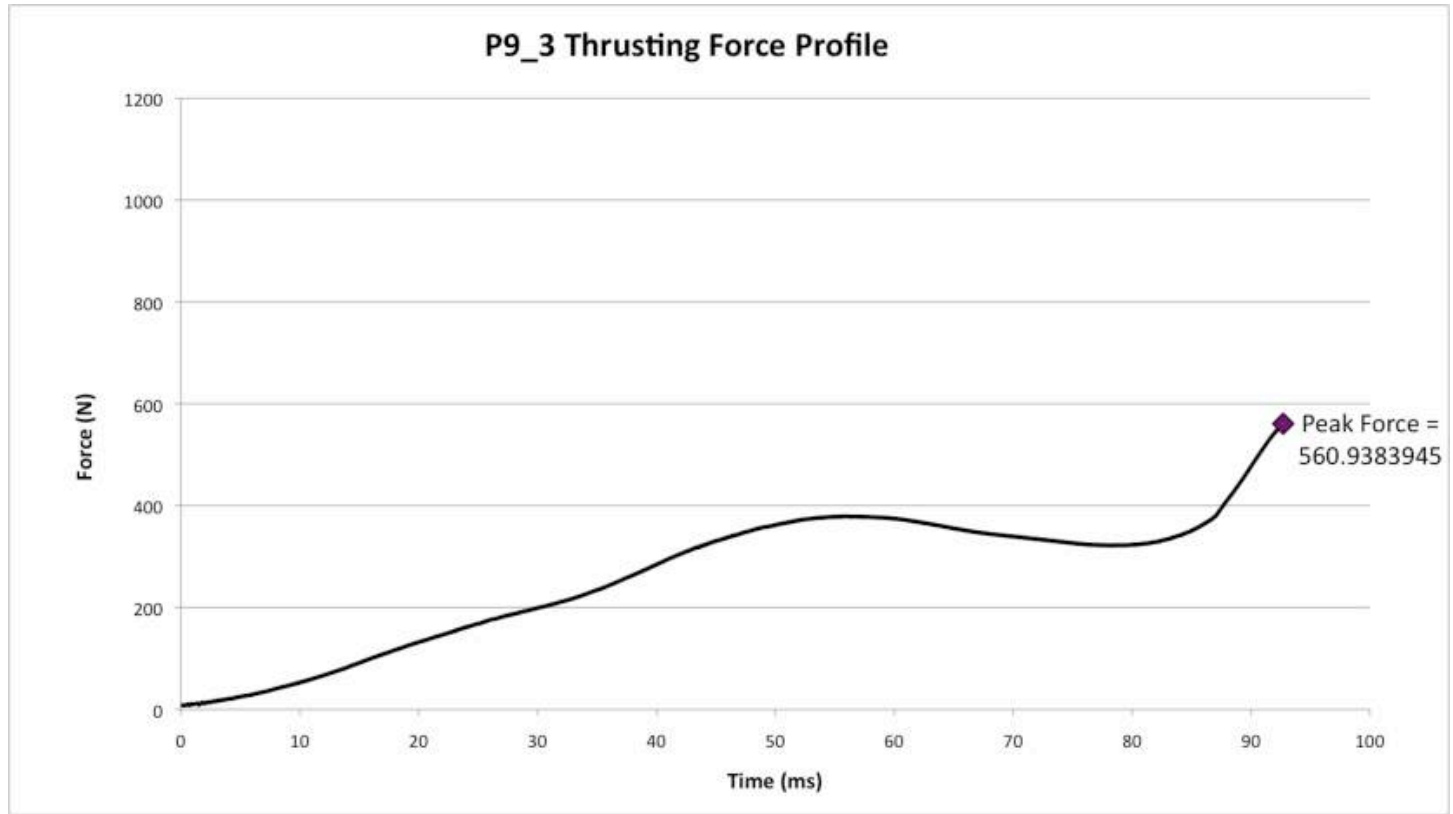

Figure 18. Example of a 'push' force-time profile (participant 9, replicate 3).

PermaGel ${ }^{\mathrm{TM}}$ blocks were changed after Replicate P4_3 and P8_3, with a mean of 13 thrusts per block, and therefore it is important to demonstrate that the use of a target for multiple thrusts, given the diameter of the spears, did not greatly affect peak force values. Figure 16 demonstrates that there is not a downward trend from initial impact into an unused block until the final replicate into the block. In one case (replicate P10_1, case number 28) the 
thrust converged with that of a previous thrust, and this was noted. For blocks 2 and 3, the final thrust into the block was greater than the mean of thrusts by that block. For block 1 the mean peak force was $756.6 \mathrm{~N}(\mathrm{n}=12)$ and the final thrust for the block was $616 \mathrm{~N}$. For block 2 the mean peak force was $685 \mathrm{~N}$ $(n=12)$ and the final thrust for the block achieved 904 N. For block 3 the mean peak force was $557.3 \mathrm{~N}(\mathrm{n}=15)$ and the final thrust for the block was $600 \mathrm{~N}$. Therefore the use of blocks for multiple thrusts is unlikely to have greatly affected the force results, as multiple thrusts to the same locations would demonstrate a decreasing trend in the forces needed to impact the PermaGel ${ }^{\mathrm{TM}}$.

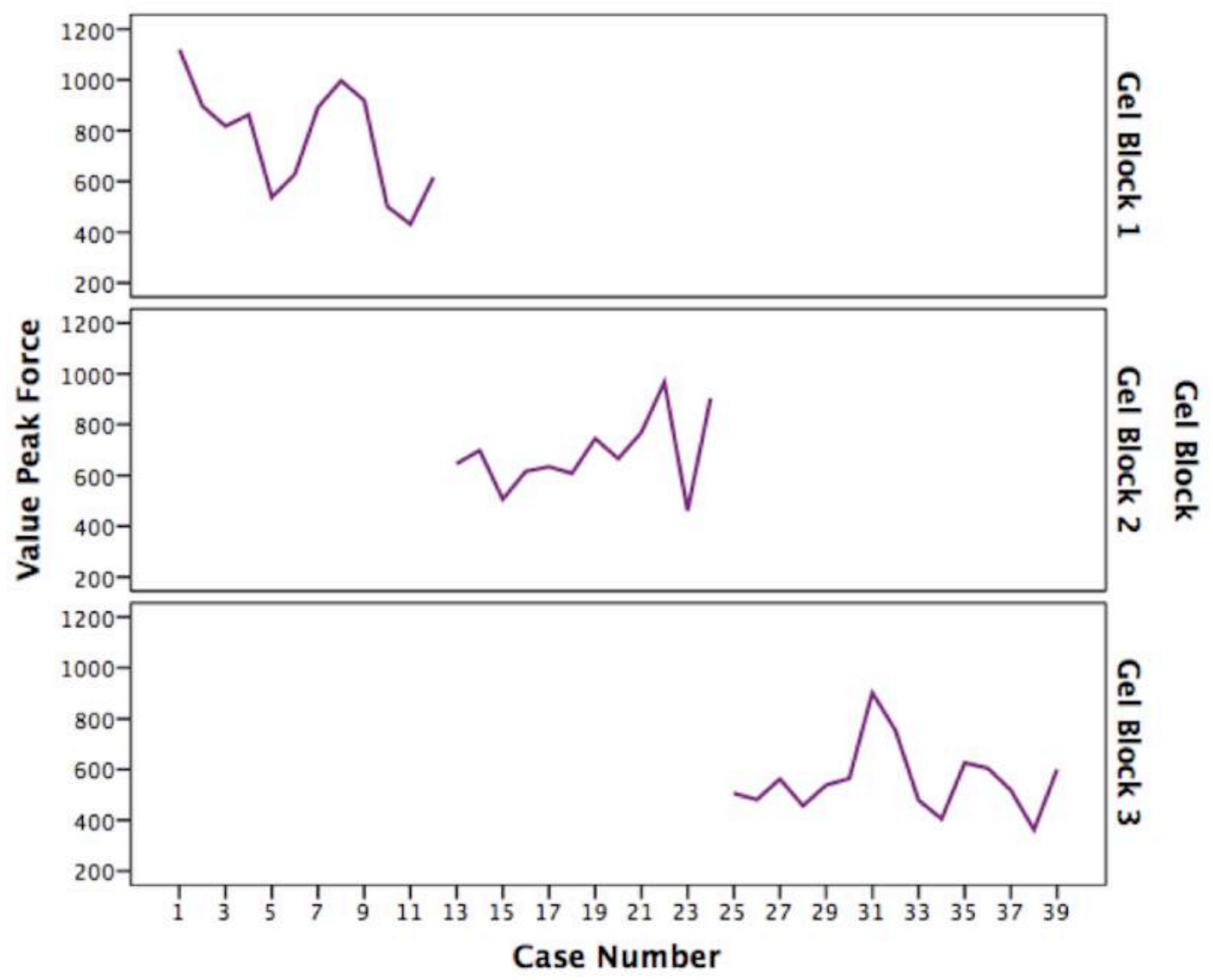

Figure 2o. Sequence of peak force values by PermaGel ${ }^{\mathrm{TM}}$ block used.

\subsection{Relating peak force and impact velocity}

A regression analysis of peak force and impact velocity per thrusting event resulted in a low $\mathrm{R}^{2}$ value of 0.139 (Figure 21), suggesting that impact velocities do not reliably predict peak force in a human spear thrusting event. 
Peak force also correlated poorly with other variables such as participant's body mass $\left(\mathrm{R}^{2}=0.012\right)$ and $\operatorname{DoP}\left(\mathrm{R}^{2}=0.034\right)$ into the target. This is not surprising given the variability in human performance in general and in the specific the complexity in the biomechanics of the two-handed thrust, discussed further below.

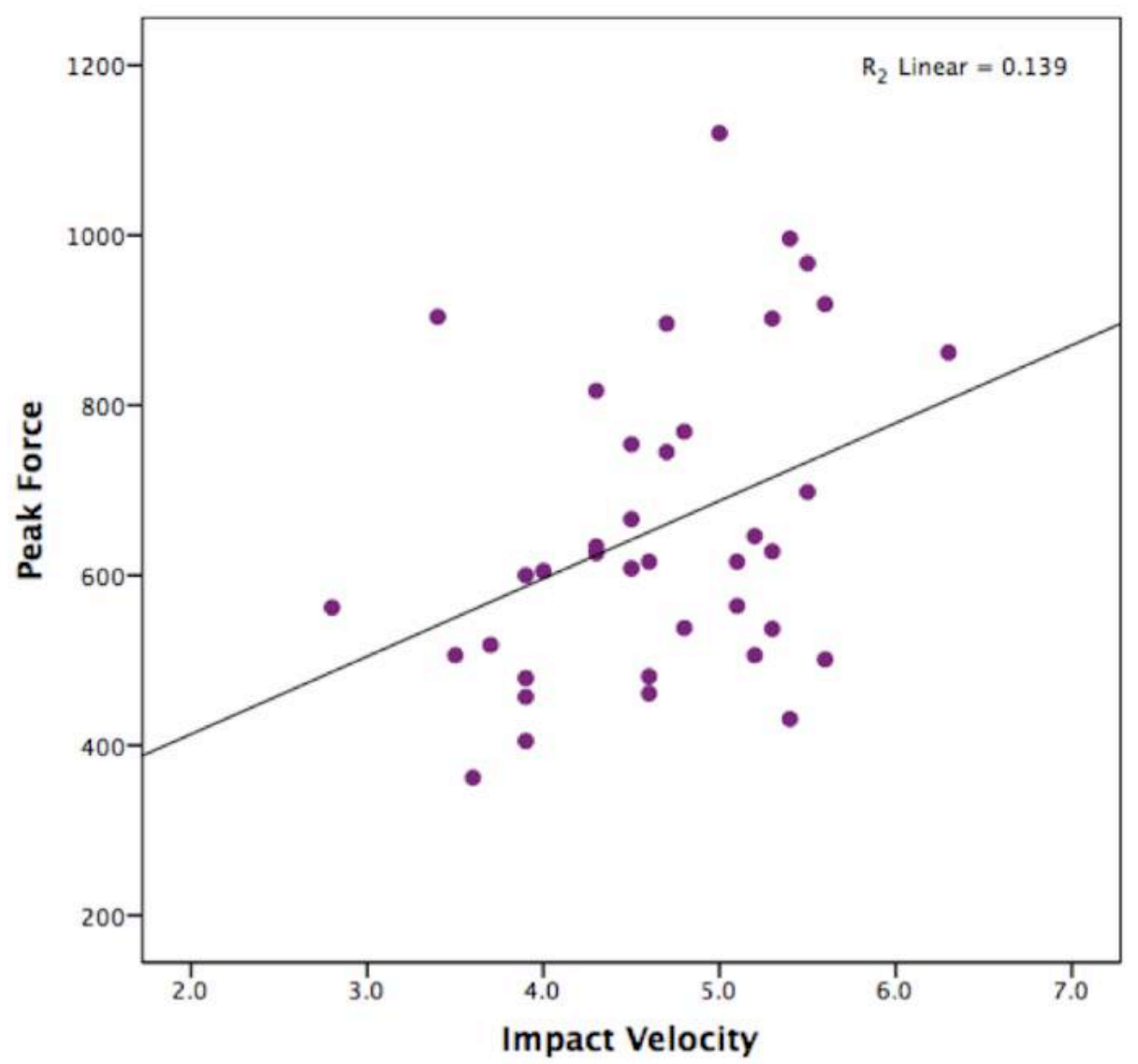

Figure 21. Regression analysis of impact velocity and peak force.

\section{Discussion}

\subsection{Impact Velocity}

Impact velocities were within the range reported for one-handed stabbing, though the mean was lower than those of all knife stabbing trials (Table 1). The range and mean compare extremely well with the small study by Connolly et al. (2001) on one-handed spear thrusting. Although some have theorised that two-handed spear thrusting should result in faster impact velocities than one-handed stabbing (Wilkins et al., 2014a), the heavier mass of the spears 
probably contributed to slower velocities, something that has also been seen in one-handed knife stabbing (Horsfall et al., 1999). As seen in Table 1, mean velocities from one-handed stabbing studies range from $5.8 \mathrm{~m} / \mathrm{s}$ to $12 \mathrm{~m} / \mathrm{s}$ depending upon stab type (e.g. underhand vs. overhand), and vary partly due to mass of the knife, with heavier knives suggested to produce slower velocities (Chadwick et al., 1999; Horsfall et al., 1999; Miller \& Jones, 1996). Schmitt et al. (2003) studied forces imparted on humans in two-handed spear thrusting with the reported range of velocities by untrained males $(n=3)$ and females ( $\mathrm{n}=5$ ) as being $1.7 \mathrm{~m} / \mathrm{s}$ to $4.5 \mathrm{~m} / \mathrm{s}$ (no mean reported) (see Table 2). The participant in Connolly et al's (2001) one-handed spear thrusting study was reportedly trained in weapon use, and achieved a mean of $4.7 \mathrm{~m} / \mathrm{s}$ and a range of $3.3 \mathrm{~m} / \mathrm{s}-6.7 \mathrm{~m} / \mathrm{s}$. Trained male participants performing two-handed spear thrusts in the current study produced a mean impact velocity of 4.65 $\mathrm{m} / \mathrm{s}$, with a maximum of $6.26 \mathrm{~m} / \mathrm{s}$, thus clearly indicating that the use of trained males results in faster impact velocities.

Researchers have been setting controlled spear thrusting experiments at velocities of either between $1.0 \mathrm{~m} / \mathrm{s}$ and $2.7 \mathrm{~m} / \mathrm{s}$, or between $7.8 \mathrm{~m} / \mathrm{s}$ and 10.3 $\mathrm{m} / \mathrm{s}$ (Table 2). Wilkins et al. (2014a; 2014b) filmed the velocity of spears fired from a crossbow at a $20 \mathrm{~kg}$ draw weight resulting in a mean impact velocity of $8.9 \mathrm{~m} / \mathrm{s}$. These results indicate that Shea et al.'s $(2002 ; 2001)$ estimated impact velocities of $1.0 \mathrm{~m} / \mathrm{s}$ to $1.5 \mathrm{~m} / \mathrm{s}$ when fired with $28 \mathrm{~kg}$ draw weight were in all probability underestimated. The wide range of velocities being tested brings into question the results of some experiments aimed at understanding lithic wear patterns and thrusting spear 'effectiveness' (e.g. Shea et al., 2002; 2001; Wilkins et al., 2014a). It also brings into question the suitability of calibrated cross-bows in replicating thrusting spear use, as others have indicated either explicitly or implicitly (e.g. Hutchings, 2011; Iovita et al., 2016; Sano et al., 2016).

\subsection{Force}

Interestingly, the maximum and mean peak forces measured in this study are comparable to that from Connolly et al.'s (2001) study on one-handed spear thrusting. However, Connolly's target was a 1 metre square piece of plywood, 
providing significant differences to our relatively small target consisting of PermaGel ${ }^{\mathrm{TM}}$. Several participants in our study observed that the need to avoid previous thrust impacts in the relatively small target area mitigated their ability to apply maximum force, an observation which has important implications for hunting scenarios.

This study has demonstrated that impact velocity and peak force have a poor correlation (Figure 21) in spear thrusting. Previous studies in stabbing and slashing and thrusting have shown that different techniques affect performance (e.g. Bleetman et al., 2003; Connolly et al., 2001; Miller and Jones, 1996). Other human performance studies have also shown high variability demonstrating that human behaviors and skills are not static (e.g. Cowper et al., 2015; Dyer, 2004; Horsfall et al., 2005; 1999). Additionally, factors such as body mass of the person and how much of that body mass they co-opt into the thrusting, fitness of the individual, technique, and spear holds will all have contributed to variations in performance achieved in this study. Adrenaline may also have played a role in spear use in the past, as challenging situations increase the adrenaline response, which can improve athletic performance (Blascovich et al., 2004). An additional complexity is that spear thrusting whether in human-human or human-animal conflict would have been a dynamic process (e.g. Bleetman et al., 2003; Rots and Plisson, 2014), with either or both parties potentially running and moving in complex ways. In a realistic hunting or violent encounter these multiple factors would have come together to produce an action with high variability, with some factors mitigating and others enhancing performance. Studies on human performance in other prehistoric weapon technologies have also found variability, which include many factors that may include body morphology and stature, fitness, age, skill, and even possibly gender (e.g. Apicella, 2014; Maki, 2013; Whittaker \& Kamp, 2006; J. Whittaker, pers. comm. 2016).

\subsection{Replicating two-handed spear thrusting}

Thrusting spears remain in the hand in use, and therefore are not projectile weapons (Hughes, 1998; Hutchings, 2011). Their mechanics differ from those of projectiles and this should be reflected in how they are replicated in 
experimental work. A person using a thrusting spear literally puts their body mass behind the weapon. This is true whether an 'on guard' standing position is used, such as that used in the current experiment, or an overhead stabbing such as those observed by Kortlandt (2002) by native hunters in the former Belgian Congo. Modern day troops undergoing bayonet training practice stabbing dummies on the ground as well, either pushing with the body in a downward motion, or by bending the knees and leaning over the target (Ripley 1999, p.15). In either position, a pushing movement carries on after initial impact, and while deceleration happens after contact in stabbing (Horsfall et al., 1999), this motion differs from that of a projectile, which loses momentum upon impact and thus relies entirely upon kinetic energy at impact and the object's tip design to penetrate the target. In stabbing and thrusting motions, the person using the weapon makes decisions in response to the target, and may carry on producing momentum on the weapon after impact, until satisfied with DoP or upon hitting something impenetrable with the weapon (Hutchings, 2011).

By analysing knife impacts used in a drop tower, Chadwick et al. (1999) demonstrated that only two measures out of the three involved in stabbing velocity, momentum and energy - are matched at any time to actual knife stabbing by human participants. Because of mechanical differences between thrusting spears and projectile weapons, it is clear that impact velocity alone cannot accurately replicate thrusting spear mechanics (Hutchings, 2011; Iovita et al., 2016; Sano et al., 2016). Firing a spear as a projectile, for example by crossbow or air-cannon, can mimic impact velocities, but not the changes to momentum in the thrusting action after initial impact (Hutchings, 2011; Iovita et al., 2016; Sano et al., 2016). Therefore using such equipment, even if set to replicate the impact velocities from this study, will fail to fully replicate spear thrusting. Adding mass to the mechanism to replicate loading on the target, like Iovita et al. (2016) do, may go some way to modeling spear thrusting mechanics. Using drop towers and air-cannons, while they can accurately simulate the correct impact velocities (unlike calibrated cross-bows) is still less than ideal (Chadwick et al., 1999). Sacrificing experimental control gained by mechanical methods and manually thrusting, such as many already do (e.g. 
Clarkson, 2016; Hutchings, 2011; Lombard et al., 2004; Parsons and Badenhorst, 2004; Rots, 2016; Sano et al., 2016) currently best replicates spear thrusting mechanics and is a frequently utilised method in impact and armour research (e.g. Bleetman et al., 2003; Cowper et al., 2015; Kemp et al., 2009). The sacrifice of control can be limited by using a small number of welltrained individuals. The data provided here support hypotheses that the use of trained participants will influence outcomes of experimental work of this kind (e.g. Rots and Plisson, 2014). If thrusting replicas mechanically is preferred for purposes of experimental control, the current paper provides ranges and means for impact velocity and force data, which will facilitate the use of equipment such as testing rigs by enabling the calculation of appropriate loads (e.g. Gilchrist et al., 2008; Iovita et al., 2016). Future experimentation on the mechanics and biomechanics of thrusting spears should focus upon isolating the effects of using an animal carcass, of spear mass, and the use of lithic and bone points, all of which may have varying effects upon force and velocity values.

\section{Conclusions}

It is a fair assumption that human groups who were reliant, even in part, on large meat packages for their survival, would have had members of the group who were fit, aggressive and highly experienced in the technologies and strategies that enabled both confrontational scavenging and hunting. Spear technologies such as those found at Schöningen would have provided not only the means to potentially hunt swift flight animals such as horses, but also to compete with and defend themselves against dangerous animals in their environment such as sabre-toothed cats, wild boar and wolves (Serangeli et al., 2014; van Kolfschoten, 2014). Better understanding technologies enabling both subsistence and self-defence in the Middle Pleistocene provides important insight into human-animal interactions during this period.

This human performance trial has provided data facilitating a better understanding of the mechanics and biomechanics of two-handed spear thrusting. As the first study linking impact velocities and forces on spears of two-handed spear thrusting, it demonstrates a complexity even when using 
trained participants, due to human variability in technique and physiological capabilities. The range and variability in human performance evident from this study indicates the need for further human performance studies in prehistoric technologies in order to more fully understand potential overlaps in parameters such as velocities. These data are key for evaluating existing results from spear thrusting experimental research, and provide a framework for developing new methodologies in understanding this hunting technology. Future experimental work on hunting lesions, 'effectiveness' of untipped, lithic- and organic-tipped thrusting weapons, and damage signatures on weapons will need to re-evaluate existing methodologies for mechanically replicating thrusting spear use in light of these results.

Identifying the development of the use of thrusting spears in the archaeological record can enhance discussions on human-animal interactions, social group hunting and/or scavenging strategies, and even possibly early indications of interpersonal violence. Thrusting spears have continued to be a part of modern human hunters' toolkits, and thus the study provides a better understanding of the use of this delivery method from the earliest signals of hunting in the archaeological record through to recent hunter-gatherer groups.

\section{Acknowledgments}

The authors gratefully acknowledge and thank UCL's Centre for Humanities Interdisciplinary Research Projects (CHIRP) for a grant covering the expenses of this experiment and Arts and Humanities Research Council (AHRC) for funding the PhD research of Annemieke Milks, to which this research is contributing. We would like to thank Prof. Ian Horsfall for enabling a subsidised use of the facilities at Cranfield Defence and Security for our research purposes, and all of our participants in the study for their contributions and interesting conversations. Thanks for William Barker for taking photographs on the day of the experiment. Two anonymous reviewers made useful suggestions for improving the paper, and we are grateful for their insights and comments. We would also like to thank Dan Luscombe and Bedgebury Pinetum for donating the spruce trees for the spear replicas. 


\section{References}

Adam, K., 1951. Der Waldelefant von Lehringen, eine Jagdbeute des diluvialen Menschen. Quätar 5, 79-92.

Apicella, C.L., 2014. Upper-body strength predicts hunting reputation and reproductive success in Hadza hunter-gatherers. Evolution and Human Behavior 35, 508-518. doi:10.1016/j.evolhumbehav.2014.07.001

Blascovich, J., Seery, M.D., Mugridge, C.A., Norris, R.K., Weisbuch, M., 2004. Predicting athletic performance from cardiovascular indexes of challenge and threat. Journal of Experimental Social Psychology 40, 683-688. doi:10.1016/j.jesp.2003.10.007

Bleetman, A., Watson, C.H., Horsfall, I., Champion, S.M., 2003. Wounding patterns and human performance in knife attacks: optimising the protection provided by knife-resistant body armour. Journal of Clinical Forensic Medicine 10, 243-248. doi:10.1016/j.jcfm.2003.09.005

Bridgland, D.R., Field, M.H., Holmes, J.A., McNabb, J., 1999. Middle Pleistocene interglacial Thames-Medway deposits at Clacton-on-Sea, England: reconsideration of the biostratigraphical and environmental context of the type Clactonian industry. Quaternary Science Reviews 18, 109-146. doi:10.1016/S0277-3791(97)00092-9

Chadwick, E.K., Nicol, A.C., Lane, J.V., Gray, T.G., 1999. Biomechanics of knife stab attacks. Forensic Science International 105, 35-44.

Churchill, S.E., 1993. Weapon Technology, Prey Size Selection, and Hunting Methods in Modern Hunter-Gatherers: Implications for Hunting in the Palaeolithic and Mesolithic. Archeological Papers of the American Anthropological Association 4, 11-24. doi:10.1525/ap3a.1993.4.1.11

Churchill, S.E., Franciscus, R., McKean-Peraza, H.A., Daniel, J., Warren, B.R., 2009. Shanidar 3 Neandertal rib puncture wound and paleolithic weaponry. Journal of Human Evolution 57, 163-178.

Churchill, S.E., Rhodes, J.A., 2009. The Evolution of the Human Capacity for "Killing at a Distance": The Human Fossil Evidence for the Evolution of Projectile Weaponry, in: Hublin, J.-J., Richards, M.P. (Eds.), The Evolution of Hominin Diets. Springer, pp. 201-210.

Clarkson, C., 2016. Testing Archaeological Approaches to Determining Past Projectile Delivery Systems Using Ethnographic and Experimental Data, in: Iovita, R., Sano, K. (Eds.), Multidisciplinary Approaches to the Study of Stone Age Weaponry. Springer, Vertebrate Paleobiology and Paleoanthropology Series. Cham, Switz, pp. 189-202.

Clastres, P., 1972. The Guayaki, in: Bicchieri, M. (Ed.), Hunters and Gatherers Today: Socioeconomic Study of Eleven Such Cultures in the Twentieth Century. Waveland Press, Prospect Heights, pp. 138-174.

Conard, N.J., Serangeli, J., Böhner, U., Starkovich, B.M., Miller, C.E., Urban, B., van Kolfschoten, T., 2015. Excavations at SchOningen and paradigm shifts in human evolution. Journal of Human Evolution 1-17. doi:10.1016/j.jhevol.2015.10.003

Connolly, P., Sim, D., Watson, C., 2001. An evaluation of the effectiveness of three methods of spear grip used in antiquity. Journal of Battlefield Technology 4, 4954.

Cowper, E.J., Carr, D.J., Horsfall, I., Fergusson, S.M., 2015. The effect of fabric and stabbing variables on severance appearance. Forensic Science International 249, 
214-224. doi:10.1016/j.forsciint.2015.01.024

Cowper, E.J., Mahoney, P.F., Godhania, K., Carr, D.J., Harrison, K., 2016. A pilot study examining garment severance damage caused by a trained sharp-weapon user. Textile Research Journal 0040517516651107. doi:10.1177/0040517516651107

Dart, R.A., 1949. The predatory implemental technique of Australopithecus. Am. J. Phys. Anthropol. 7, 1-38.

Darwin, C., 1871. The descent of man; and Selection in relation to sex; with an introduction by H. James Birx. Amherst, NY : Prometheus Books.

Davidson, D.S., 1936. The spearthrower in Australia. Proceedings of the American Philosophical Society 76, 445-483.

Davidson, D.S., 1934. Australian Spear-traits and Their Derivations. The Journal of the Polynesian Society 43, 41-72.

Driver, H.E., 1939. Culture element distributions: X Northwest California. Anthropological Records 1, 297-433.

Dyer, J., 2004. The measurement of individual and unit expertise, in: The Science and Simulation of Human Performance, Advances in Human Performance and Cognitive Engineering Research. Elsevier, pp. 11-124. doi:10.1016/S14793601(04)05001-5

Froehle, A.W., Yokley, T.R., Churchill, S.E., 2013. Energetics and the Origin of Modern Humans, in: Smith, F.H., Ahern, J.C.M. (Eds.), The Origins of Modern Humans. Wiley, Hoboken, NJ, pp. 285-320.

Gamble, C., 1987. Man the Shoveler: alternative models for middle Pleistocene colonization and occupation in northern latitudes., in: Soffer, O. (Ed.), The Pleistocene Old World : Regional Perspectives. New York; London : Plenum, pp. 81-98.

Gilchrist, M.D., Keenan, S., Curtis, M., Cassidy, M., Byrne, G., Destrade, M., 2008. Measuring knife stab penetration into skin simulant using a novel biaxial tension device. Forensic Science International 177, 52-65. doi:10.1016/j.forsciint.2007.10.010

Goodale, J.C., 1994. Tiwi Wives: a study of the women of Melville Island, North Australia. Prospect Heights III, Waveland Pr.

Guthrie, R.D., 2005. The Nature of Paleolithic Art. University of Chicago Press.

Hardy, B.L., Moncel, M.-H., Daujeard, C., Fernandes, P., Béarez, P., Desclaux, E., Chacon Navarro, M.G., Puaud, S., Gallotti, R., 2013. Impossible Neanderthals? Making string, throwing projectiles and catching small game during Marine Isotope Stage 4 (Abri du Maras, France). Quaternary Science Reviews 82, 23-40. doi:10.1016/j.quascirev.2013.09.028

Hatala, K.G., Roach, N.T., Ostrofsky, K.R., Wunderlich, R.E., Dingwall, H.L., Villmoare, B.A., Green, D.J., Harris, J.W.K., Braun, D.R., Richmond, B.G., 2016. Footprints reveal direct evidence of group behavior and locomotion in Homo erectus. Nature Publishing Group 1-9. doi:10.1038/srep28766

Hiatt, B., 1968. The Food Quest and the Economy of the Tasmanian Aborigines (Continued). Oceania 38, 190-219. doi:10.2307/40329716

Hitchcock, R., Bleed, P., 1997. Each According to Need and Fashion: Spear and Arrow Use among San Hunters of the Kalahari, in: Knecht, H. (Ed.), Projectile Technology. Plenum Press, New York, pp. 345-368.

Horsfall, I., Prosser, P.D., Watson, C.H., Champion, S.M., 1999. An assessment of human performance in stabbing. Forensic Science International 102, 79-89.

Horsfall, I., Watson, C., Champion, S., Prosser, P., Ringrose, T., 2005. The effect of 
knife handle shape on stabbing performance. Appl Ergon 36, 505-511. doi:10.1016/j.apergo.2004.12.001

Huffman, M., Kalunde, M., 1993. Tool-assisted predation on a squirrel by a female chimpanzee in the Mahale Mountains, Tanzania. Primates 34, 93-98.

Hughes, S.S., 1998. Getting to the point: evolutionary change in prehistoric weaponry. J Archaeol Method Theory 5, 345-408.

Hutchings, W.K., 2011. Measuring use-related fracture velocity in lithic armatures to identify spears, javelins, darts, and arrows. Journal of Archaeological Science 38, 1737-1746. doi:10.1016/j.jas.2011.03.005

Iovita, R., Schönekeß, H., Gaudzinski-Windheuser, S., Jäger, F., 2016. Identifying weapon delivery systems using macrofracture analysis and fracture propagation velocity: a controlled experiment, in: Iovita, R., Sano, K. (Eds.), Multidisciplinary Approaches to the Study of Stone Age Weaponry. Springer, Vertebrate Paleobiology and Paleoanthropology Series. Cham, Switz, pp. 13-28.

Iovita, R., Schönekeß, H., Gaudzinski-Windheuser, S., Jäger, F., 2014. Projectile impact fractures and launching mechanisms: results of a controlled ballistic experiment using replica Levallois points. Journal of Archaeological Science 48, 73-83. doi:10.1016/j.jas.2013.01.031

Kemp, S.E., Carr, D.J., Kieser, J., Niven, B.E., Taylor, M.C., 2009. Forensic evidence in apparel fabrics due to stab events. Forensic Science International 191, 86-96. doi:10.1016/j.forsciint.2009.06.013

Kortlandt, A., 2002. Neanderthal anatomy and the use of spears. Evol. Anthropol. 11, 183-184. doi:10.1002/evan.10026

Lombard, M., Parsons, I., 2010. Fact or fiction? Behavioural and technological reversal after $60 \mathrm{ka}$ in Southern Africa. The South African Archaeological Bulletin 65, 221-228.

Lombard, M., Parsons, I., van der Ryst, M.M., 2004. Middle Stone Age lithic point experimentation for macro-fracture and residue analyses: the process and preliminary results with reference to Sibudu Cave points. South African Journal of Science 100, 159-166.

Luebbers, R.A., 1975. Ancient boomerangs discovered in South Australia. Nature 253, 39-39. doi:10.1038/253039a0

Mabbott, A., Carr, D.J., Champion, S., Malbon, C., Tichler, C., 2013. Comparison of $10 \%$ gelatine, $20 \%$ gelatine and Perma-Gel ${ }^{\mathrm{TM}}$ for ballistic testing, in: Wickert, M., Salk, M. (Eds.). Presented at the 27th International Symposium on Ballistics, Freiburg, Germany April -,, pp. 648-654.

Maki, J.M., 2013. The Biomechanics of Spear Throwing: An Analysis of the Effects of Anatomical Variation on Throwing Performance, with Implications for the Fossil Record. doi:10.7936/K7NS0RVC

McBrearty, S., Brooks, A.S., 2000. The revolution that wasn't: a new interpretation of the origin of modern human behavior. Journal of Human Evolution 39, 453-563. doi:10.1006/jhev.2000.0435

Miller, S.A., Jones, M.D., 1996. Kinematics of four methods of stabbing: a preliminary study. Forensic Science International 82, 183-190.

Moseley, H.N., 1877. On the Inhabitants of the Admiralty Islands, Etc. The Journal of the Anthropological Institute of Great Britain and Ireland 6, 379-429.

Noetling, F., 1911. Notes on the hunting sticks (lughkana), spears (perenna), and baskets (tughbrana) of the Tasmanian Aborigines. Papers and Proceedings of the Royal Society of Tasmania 64-98.

Oakley, K., Andrews, P., Keeley, L., Clark, J.D., 1977. A Reappraisal of the Clacton 
Spearpoint. Proceedings of the Prehistoric Society 43, 13-30.

Palter, J.L., 1977. Design and construction of Australian spear-thrower projectiles and hand-thrown spears. Archaeology \& Physical Anthropology in Oceania 12, 161172.

Parsons, I., Badenhorst, S., 2004. Analysis of lesions generated by replicated Middle Stone Age lithic points on selected skeletal elements: research letter. South African Journal of Science 100, 384-387.

Pruetz, J., Bertolani, P., 2007. Savanna Chimpanzees, Pan troglodytes verus, Hunt with Tools. Current Biology 17, 412-417.

Rhodes, J.A., Churchill, S.E., 2009. Throwing in the Middle and Upper Paleolithic: inferences from an analysis of humeral retroversion. Journal of Human Evolution $56,1-10$.

Richter, D., Krbetschek, M., 2015. The age of the Lower Palaeolithic occupation at Schöningen. Journal of Human Evolution 1-11. doi:10.1016/j.jhevol.2015.06.003

Rieder, H., 2003. Der Große Wurf der frühen Jäger: Nachbau altsteinzeitlicher Speere. Biologie in unserer Zeit 33, 156-160.

Rieder, H., 2001. Erprobung der Holzspeere von Schoeningen (400000 Jahre) und Folgerungen daraus, in: Wagner, G.A., Mania, D. (Eds.), Fruhe Menschen in Mittel Europa: Chronologie, Kultur, Umwelt. Shaker, Aachen, pp. 91-98.

Ripley, T., 1999. Bayonet battle: bayonet warfare in the twentieth century. Sidgwick \& Jackson, London.

Roach, N., Venkadesan, M., Rainbow, M., Lieberman, D., 2013. Elastic energy storage in the shoulder and the evolution of high-speed throwing in Homo. Nature 498, 483-487. doi:doi:10.1038/nature12267

Roach, N.T., Richmond, B.G., 2015. Clavicle length, throwing performance and the reconstruction of the Homo erectus shoulder. Journal of Human Evolution 80, 107-113. doi:10.1016/j.jhevol.2014.09.004

Rots, V., 2016. Projectiles and Hafting Technology, in: Iovita, R., Sano, K. (Eds.), Multidisciplinary Approaches to the Study of Stone Age Weaponry. Springer, Vertebrate Paleobiology and Paleoanthropology Series. Cham, Switz, pp. 167185.

Rots, V., 2009. The functional analysis of the Mousterian and Micoquian assemblages of Sesselfelsgrotte, Germany: aspects of tool use and hafting in the European Late Middle Palaeolithic. Quartär 56, 37-66.

Rots, V., Plisson, H., 2014. Projectiles and the abuse of the use-wear method in a search for impact. Journal of Archaeological Science 48, 154-165. doi:10.1016/j.jas.2013.10.027

Sala, N., Arsuaga, J.-L., Pantoja-Pérez, A., Pablos, A., Martínez, I., Quam, R.M., Gómez-Olivencia, A., Bermúdez de Castro, J.M., Carbonell, E., 2015. Lethal Interpersonal Violence in the Middle Pleistocene. PLoS ONE 10, e126589-12. doi:10.1371/journal.pone.0126589

Sano, K., Denda, Y., Oba, M., 2016. Experiments in fracture patterns and impact velocity with replica hunting weapons from Japan, in: Iovita, R., Sano, K. (Eds.), Multidisciplinary Approaches to the Study of Stone Age Weaponry. Springer, Vertebrate Paleobiology and Paleoanthropology Series. Cham, Switz, pp. 29-46.

Schmitt, D., Churchill, S.E., Hylander, W.L., 2003. Experimental Evidence Concerning Spear Use in Neandertals and Early Modern Humans. Journal of Archaeological Science 30, 103-114. doi:10.1006/jasc.2001.0814

Schoch, W.H., Bigga, G., Böhner, U., Richter, P., Terberger, T., 2015. New insights on the wooden weapons from the Paleolithic site of Schöningen. Journal of 
Human Evolution 89, 214-225. doi:10.1016/j.jhevol.2015.08.004

Serangeli, J., van Kolfschoten, T., Conard, N.J., 2014. 300.000 Jahre alte Funde einer Säbelzahnkatzeaus Schöningen - Die gefährlichste Raubkatze der Eiszeit erstmals für Norddeutschland belegt. Berichte zur Denkmalpflege in Niedersachsen 10-12. Shea, J., 2006. The origins of lithic projectile point technology: evidence from Africa, the Levant, and Europe. Journal of Archaeological Science 33, 823-846.

Shea, J., Brown, K., Davis, Z., 2002. Controlled experiments with Middle Palaeolithic spear points: Levallois points, in: Mathieu, J.R. (Ed.), Scavenging or Hunting in Early Hominids: Theoretical Framework and Tests. BAR International Series, Oxford, pp. 55-72.

Shea, J., Davis, Z., Brown, K., 2001. Experimental Tests of Middle Palaeolithic Spear Points Using a Calibrated Crossbow. Journal of Archaeological Science 28, 807816. doi: $10.1006 /$ jasc. 2000.0590

Shea, J., Sisk, M., 2010. Complex projectile technology and Homo sapiens dispersal into western Eurasia. PA 2010, 100-122.

Sisk, M.L., Shea, J.J., 2011. The african origin of complex projectile technology: an analysis using tip cross-sectional area and perimeter. International Journal of Evolutionary Biology 2011, 968012-8. doi:10.4061/2011/968012

Spencer, W.B., 1914. Native tribes of the northern territory of Australia. London : Macmillan and Co.

Stewart, K.M., 1947. Mohave Warfare. Southwestern Journal of Anthropology 3, $257-278$.

Street, M., Terberger, T., Orschiedt, J., 2006. A critical review of the German Paleolithic hominin record. Journal of Human Evolution 51, 551-579. doi:10.1016/j.jhevol.2006.04.014

Stringer, C.B., 2012. The status of Homo heidelbergensis (Schoetensack 1908). Evol. Anthropol. 21, 101-107. doi:10.1002/evan.21311

Stringer, C.B., Trinkaus, E., Roberts, M.B., Parfitt, S.A., Macphail, R.I., 1998. The Middle Pleistocene human tibia from Boxgrove. Journal of Human Evolution 34, 39-39. doi:10.1006/jhev.1998.0215

Swanton, J.R., 1946. The Indians of the Southeastern United States. Bulletin of the Bureau of American Ethnology 137, 1-104.

Thieme, H., 1999a. Altpaläolithische Holzgeräte aus Schöningen, Lkr. Helmstedt, Bedeutsame Funde zur Kulturentwicklung des frühen Menschen. Germania 77, 451-487.

Thieme, H., 1999b. Lower Palaeloithic Throwing Spears and Other Wooden Implements From Schoeningen, Germany, in: Ullrich, H. (Ed.), Hominid Evolution : Lifestyles and Survival Strategies. Gelsenkirchen Germany : Edition Archaea, pp. 383-395.

Thieme, H., 1997. Lower Palaeolithic hunting spears from Germany. Nature 385, 807-810.

Trinkaus, E., Stringer, C.B., Ruff, C.B., Hennessy, R.J., 1999. Diaphyseal crosssectional geometry of the Boxgrove 1 Middle Pleistocene human tibia. Journal of Human Evolution 37, 1-25. doi:10.1006/jhev.1999.0295

Urban, B., Sierralta, M., Frechen, M., 2011. New evidence for vegetation development and timing of Upper Middle Pleistocene interglacials in Northern Germany and tentative correlations. Quaternary International 241, 125-142.

van Kolfschoten, T., 2014. The Palaeolithic locality Schöningen (Germany): A review of the mammalian record. Quaternary International 326-327, 469-480.

doi:10.1016/j.quaint.2013.11.006 
Villa, P., Soriano, S., 2010. Hunting weapons of Neanderthals and early modern humans in South Africa: similarities and differences. Journal of Anthropological Research 66, 5-38.

Washburn, S.L., Washburn, S.L., Lancaster, C.S., 1968. The Evolution of Hunting, in: Lee, R., Devore, I. (Eds.), Man the Hunter. Chicago : Aldine Pub.Co., pp. 293303.

Whittaker, J.C., Kamp, K.A., 2006. Primitive Weapons and Modern Sport: Atlatl Capabilities, Learning, Gender, and Age. Plains Anthropologist 51, 213-221. doi:10.1179/pan.2006.016

Wilkins, J., Schoville, B.J., Brown, K.S., 2014a. An Experimental Investigation of the Functional Hypothesis and Evolutionary Advantage of Stone-Tipped Spears.

PLoS ONE 9, e104514. doi:10.1371/journal.pone.0104514

Wilkins, J., Schoville, B.J., Brown, K.S., 2014b. Supplementary Information for: An Experimental Investigation of the Functional Hypothesis and Evolutionary Advantage of Stone-Tipped Spears. PLoS ONE 1-8.

Wilkins, J., Schoville, B.J., Brown, K.S., Chazan, M., 2012. Evidence for early hafted hunting technology. Science 338, 942-946. doi:10.1126/science.1227608 